Adıgüzel, F. B. ve Süslü, G. (2017). "Yaratıcı dramayla kitap kurdu olunur mu?” çocuk kitaplarıyla okuma sevgisi ve ilgisi kazandırma. Ana Dili Eğitimi Dergisi, 5(3), 367-394.

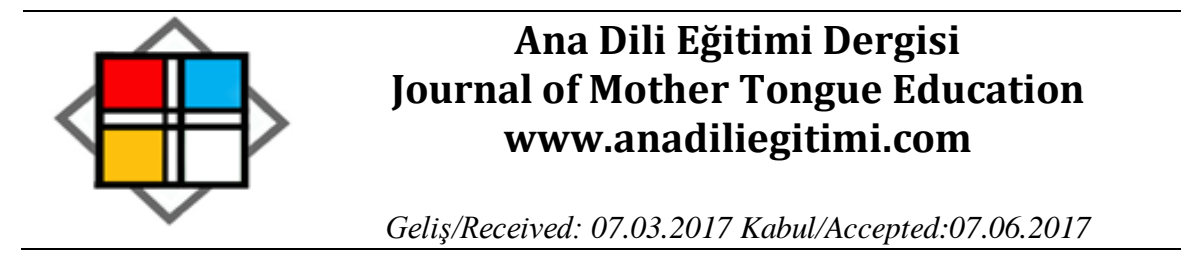

\title{
"Yaratıcı Dramayla Kitap Kurdu Olunur mu?" Çocuk Kitaplarıyla Okuma Sevgisi ve İlgisi Kazandırma
}

\author{
Ferah Burgul ADIGÜZEL* \\ Gökhan SÜSLÜ̈*
}

Öz

Bu çalışmanın amacı, 3. sınıf öğrencilerinin çocuk kitaplarıyla okuma sevgisi ve ilgisi kazanmasında yaratıcı drama yönteminin kullanılmasına ilişkin görüşlerini belirlemektir. Öğrenci görüşlerinden yararlanılan bu çalışma nitel bir araştırmadır. Araştırma 2015-2016 eğitim öğretim yılında İzmir ilinin bir ilçesinde yer alan bir devlet ilköğretim okulunda 3. sınıfta okumakta olan 9 öğrenci ile yürütülmüştür. Araştırmanın uygulama aşaması 07.04.2016-09.05.2016 tarihleri arasında 4 haftalık süreçte gerçekleştirilmiştir. Araştırma kapsamında on bir oturum gerçekleştirilerek 18 saat 30 dakikalık uygulama gerçekleştirilmiştir. Çalışma kapsamında ulaşılan veriler; açık uçlu sorulardan oluşan "Okuma İlgisi/isteği Soru Kâğıdı”, katılımcılar tarafından gerçekleştirilen her atölyenin sonunda doldurulan "Okuma Günlüğü" ve ders öğretmeni tarafından her atölye çalışması ardından gözlemlerin yazıldığı "Araştırmacı Günlüğü" aracılığıyla elde edilmiştir. Araştırmadan elde edilen verilerin analizinde betimsel analiz kullanılmıştır. Araştırma sonuçlarına göre; yaratıcı dramayla gerçekleştirilen okuma etkinliklerinin ardından öğrencilerin okumayı sevme durumlarında bir değişiklik olmamıştır. Ancak kitaplarda anlatılan hikâyelerin canlandırıldığı atölye çalışmalarının ardından öğrencilerin anlatılanları canlandırabildikleri yani somutlaştırabildikleri belirlenmiştir. Yaratıcı drama çalışmalarının öğrencilerin okuma sıklığını tam anlamıyla geliştirmediği ancak daha düzenli bir şekilde yürütmelerini desteklediği belirlenmiştir. Öğrencilerin çoğunluğu yaratıcı dramayla gerçekleştirilen kitap okuma atölyelerinde belirlenen kazanımlara ulaşmış olup atölye sonlarında gerçekleşen kitap okuma etkinliğine istekli bir şekilde katılmışlardır.

Anahtar Sözcükler: Yaratıcı Drama, Okuma Sevgisi ve İsteği, Çocuk Kitapları

\section{"Is it Possible to Become a Bookworm with Creative Drama?" Provision of Passion and Interest for Reading with Children's Books}

\begin{abstract}
The purpose of this article is to determine the opinions of the 3rd grade students about the use of creative drama method in children's books to gain passion and interest for reading. This study, which is based on student opinions, is a qualitative research. The study was conducted with 9 students studying in the 3rd grade in a state primary school in a province of Izmir in the academic year of 2015-2016. The implementation phase of the study was carried out between 04.04.201609.05.2016 for 4 weeks. In the scope of the research, eleven sessions were held for 18 hours and 30 minutes. The data obtained within the scope of the study were obtained through the "Reading Interest/Demand Questionnaire" consisting of open-ended questions, the "Reading Diary" filled
\end{abstract}

* Dr., Gazi Üniversitesi Gazi Eğitim Fakültesi Türk Dili ve Edebiyatı Eğitimi ABD, Ankara. fburgul@gmail.com

** Öğretmen, Ahmet Şefika Kilimci Özel Eğitim Okulu, Konak/İzmir. gokhan.suslu@hotmail.com 
out at the end of each workshop conducted by the participants, and the "Investigator Diary" written by the course teacher after each workshop study. Descriptive analysis was used in the analysis of the data obtained from the study. According to the results of the research, there has not been a change in the students' liking to read after the reading activities with creative drama. However, after the workshops in which the stories described in the books were portrayed, it was found that the students could personify thus concretize what they had read. It was found that creative drama works do not fully develop the reading frequency of students but support regularity of the reading activity. The majority of the students have attained the achievements in book reading workshops with creative drama and willingly participated in the book reading activities that took place at the end of the workshop.

Keywords: Creative Drama, Reading Passion and Desire, Children's Books

\section{Giriş}

İnsanoğlunun duygu, düşünce ve deneyim birikimini aktaran yazınsal metinler, okuru farklı duygu, düşünce ve eylem biçimiyle karşılaştırarak onlara yaşamadan yaşanmışlık kazandırır. Bu nedenle okuma; okurun bilincini, değerlerini, ilgilerini etkileyerek kendini daha iyi ve doğru biçimde ifade edebilmesine yardım eden, onun yaratıcılığının, yeteneklerini, soyut düşünebilme becerisini, hayal gücünü, zihinsel becerilerini geliştiren bilişsel ve duyuşsal boyutları olan üst düzey bir eylemdir.

Okumanın bir alışkanlığa dönüşebilmesi için okuma eyleminin sıklıkla yinelenerek kanıksanması, zamanla ihtiyaç hâlini alması, bireyin sürekli ve istendik bir okuma davranışını gerçekleştirmesi gerekir. Okuma alışkanlığı, kişinin okuma eylemini bir gereksinim olarak algılayıp yaşam boyu, sürekli ve düzenli biçimde bu eylemi gerçekleştirmesidir. Okuma alışkanlığı; çocuğun zihinsel gelişimine katkıda bulunur, anadilini doğru ve etkili bir biçimde kullanmasını sağlar, kelime dağarcı̆ı̆ını zenginleşmesine yardım eder, sağlıklı ve güçlü bir kişilik geliştirmesine katkıda bulunur, iletişim becerisinin güçlenmesine yardımcı olur ve eğitim başarısını artırır. Kısacası kitap okuma alışkanlığı çocuğa hayal dünyasını ve fikir üretme becerisini geliştirme yolunda ona katkı sağlar. Bir çocuğun farklı bakış açılarına sahip olması onu hayatta bir adım öne çıkartır. Farklı bakış açılarına sahip bir çocuk özgüveni yüksek, temel dil becerilerini kazanmış, empati kurma yetisine sahip, yani kendini gerçekleştirmeye yeterli bir birey olarak toplumdaki yerini daha kolay alabilecektir. "Okuma, bireyin entelektüel gelişimini sağlamakta; anlama gücünü geliştirmekte; başkalarıyla iletişimini kolaylaştırmakta, eleştirel düşünce yapısına temel oluşturmaktadır. Bundan dolayı okuma alışkanlığı, temel okur-yazarlığın ötesinde bir kavram olarak tanımlanmaktadır" (Kurulgan ve Çekerol, 2008: 239).

Bir toplumun gelişmişlik düzeyini yansıtan önemli göstergelerden biri olarak kabul edilen okuma alışkanlığı ve kütüphane kullanımı (Odabaş, Odabaş ve Polat, 2008: 431) açısından Türkiye incelendiğinde, Türkiye'de özellikle ilköğretim düzeyindeki çocukların okuma alışkanlıkları incelendiğinde Türkiye'deki çocukların okuma becerileri açısından 35 ülke arasında 28. sırada olduğu ve kitabın ihtiyaç maddeleri sıralamasındaki yerinin 235. sıra olduğu görülmektedir (Çocuk Vakfı 
Çocuk Edebiyatı Okulu, 2006). Yılmaz (2004: 121- 129)'ın Ankara'daki beşinci sınıf öğrencileri ile yaptığı bir araştırmada da öğrencilerin yaklaşık \% 70'inin ya hiç kitap okumadığı ya da yalnızca iki ayda bir kitap okuduğu, öğrencilerin yarısının kütüphaneye gitme alışkanlıklarının olmadığı ve öğrencilerin annelerinin yaklaşık \% 50'sinin hiç kitap okumadığı bulunmuştur. MEB (2007) tarafından ilk ve ortaöğretim kurumlarında öğrenim gören öğrencilerle yapılan okuma düzeyi araştırması sonuçlarına göre; ilk kitap okuma yaşının $13(\% 46,63)$ ve $14(\% 16,81)$ olduğu görülmüştür. Kültür ve Turizm Bakanlığı Kütüphaneler ve Yayımlar Genel Müdürlüğü tarafından yaptırılan ve 26 ilde 6212 kişi ile gerçekleştirilen Türkiye Okuma Kültürü Haritası (TOKH, 2011) çalışması kapsamında; en çok okuyan grubun 7-14 yaş aralığındaki grup $(\% 87,5)$ olduğu, kitabın rastgele seçildiği ve düzensiz okunduğu $(\% 45,3)$, seçici ve düzenli okuyan grubun çoğunluğunun 7-14 yaş aralığındaki bireylerin (35.4) oluşturduğu ve bu grubun yılda ortalama 12 kitap okuduğu belirlenmiştir. Bu durum gençlik yayınlarına da yansımış ve 2015 yılında, 2014 yılına göre çocuk ve ilk gençlik yayınlarının \%19,2 oranında arttığı görülmüştür (TUiK, 2014). Rakamlar okuma kültürü düzeyinin oldukça düşük olduğunu ortaya koymaktadır. Bu verilere dayanarak geleneksel kitap okuma alışkanlığı kazandırma yöntemlerinin başarısız olduğu söylenebilir.

Bireylerin düzenli okuma alışkanlığına sahip olamamasının önemli nedenlerinden biri, daha başlangıç aşamasında çocuğa okuma alışkanlığının kazandırılamamasıdır (Bircan ve Tekin, 1989; Gökalp, 1998; Arıcı, 2008). Okuma alışkanlığının kazanılmasında çocukluk döneminin oldukça büyük bir öneme sahip olduğu birçok araştırmada (Alpay, 1990: 79; Yılmaz, 1998: 248) belirtilmektedir. Okuma alışkanlığına ilişkin olumlu tutum geliştirme, kitapları erken yaşta keşfetme ile aile tarafından çocuğa kitap okunması arasında anlamlı bir ilişki olduğu görülmektedir (Saracaloğlu, Bozkurt ve Serin, 2003). Çocukluk döneminde kazanılan okuma alışkanlığı, çocuğun zihinsel gelişimine ve anadili gelişimini etkileyerek sözcük dağarcığının gelişmesini sağlar.

Cleary'e göre (Akt. Bamberger, 1990: 8), “bireylerin boş zamanlarında okuma etkinliğini tercih etmesi ve gerçekleştirmesi bakımından 8-13 yaşları okumanın altın yılları olarak değerlendirilmektedir". Okuma çalışmaları, birinci sınıf sonunda programın belirttiği amaca ulaşmakla sonuçlanmadığı gibi ilkokul sonunda ve sonraki öğrenim kademelerinde de son noktasına gelemez; okumada gelişme hayat boyu sürer. Bu nedenle henüz ilkokul döneminde bu çalışmaların gerekli dikkat ve özen ile sürdürülmesi gerekir (Öz, 2001: 193). Bu nedenle okuma ilgisi çocukluk döneminde kazandırılmalı ve ergenlik döneminde desteklenerek alışkanlık haline dönüştürülmelidir (Aksaçlıoğlu ve Yılmaz, 2007: 5).

Çocuğun okuma kültürü edinme süreci, birbirine bağımlı ve birbirini bütünleyen becerilerin kazanılmasını gerekli kılan ardışık bir süreçtir. İlk basamağını dinleme becerisinin oluşturduğu bu süreç, okuma yazma becerisi, eleştirel okuma becerisi ve evrensel okuryazarlık becerisi ile devam 
etmektedir (Sever, 2013: 24). Okul öncesi dönemde anlatılan öykü, masal ve şiirler aracılığıyla kitapla iletişime giren çocuk, önce dinleme becerisiyle karşılaşarak okumaya ilişkin ilk farkındalığını edinir. İlköğretimde okumayı öğrenmesiyle birlikte temel okuma-yazma becerisine ulaşan çocuğun kendi gerçekliğine uygun metin ve kitaplarla karşılaşması ise onun okuma alışkanlığı kazanma sürecini neredeyse temelden etkiler. Çünkü nitelikli bir çocuk edebiyatının temel işlevi, küçük yaşlardan itibaren okuma sevgisi ve alışkanlığı kazandırarak çocuklarda okuma kültürü oluşmasını sağlamaktır (Gültekin, 2008: 95). Bu süreçte estetik bir eğitim aracı olan edebiyat, çocuk kitapları aracılığıyla çocuğun duygularını eğiterek onun yaşam felsefesini oluşturmasına yardımcı olur ve çocuğu nitelikli edebi ürünlere doğru yönlendirir.

Çocuğa kitap okuma kültürü kazandırmak kolay alışkanlık haline getirilebilecek bir davranış değildir. "Okumanın alışkanlık haline gelebilmesi için çocuğun okumayı bir zevk ve gereksinim olarak algılaması önemlidir" (Aksaçlıoğlu ve Yılmaz, 2007: 515). Çocukların okumayı öğrendikten sonra bu eylemi zevkle ve sürekli yapmalarını sağlayarak onlara okuma alışkanlığını kazandırmak gerekir. Bu nedenle çocukların kitaba ilişkin olumlu bir duygu geliştirmeleri ve kitabı sevmeleri için ilk iletişime geçtikleri araç olan çocuk kitaplarının önemi büyüktür. Çünkü çocuk kitaplarının en temel amacı, çocuğa okuma alışkanlığı ve sevgisi kazandırmaktır. Ayrıca çocuk kitapları çocuğun neden-sonuç ilişkisini görmesine, gelecekteki hayatına hazırlanmasına, düşünme becerisini geliştirmesine ve merak duygusu uyandırmasına yardımcı olur. Çocuk kitapları çocuğun fiziksel, zihinsel, duygusal gelişimleri ile dil gelişimine de katkıda bulunur. Çocuk kitapları aracılığıyla kendi fiziksel özelliklerini keşfeden çocuk, kitabı anlama ve sorgulama süreciyle zihinsel gelişimini sağlar, yeni kavramlar ve sözcüklere ulaşarak dil gelişimini destekler ve çocuk kitabında ele alınan konu, tema, yaşanan olaylar, kahraman ve özellikleri doğrultusunda duygusal, kişisel ve ahlaki gelişimi yaşar. Böylelikle hem kendini hem de çevresini daha iyi tanımaya ve anlamaya başlayarak birçok iyi alışkanlık edinir. "Çocuk edebiyatı metinleri çocuğa okumayı, araştırmayı, sağlıklı yaşamayı öğreterek onun duygusal yönden ruhunu diri tutar ve yaratıcı gücünü artırır. Çocuğun bilişsel, duyuşsal, devinişsel ve toplumsal gelişiminde, anadilinin inceliklerini kazanmasında çocuk edebiyatı metinlerinin önemli bir yeri vardır." (Aykaç ve Illhan, 2014: 216).

Çocukların ilköğretimin ilk yıllarında edindikleri okuma becerisini alışkanlık hâline getirebilmeleri için öncelikle ilgi, istek, ihtiyaçlarına ve doğalarına uygun yapıtlara yönlendirilmeleri gerekir. Böylece çocuk, kendi dünyasına seslenen kitapları sevmeye başlayacak, sonrasında ise okuma alışkanlığını daha kolay bir şekilde kazanabilecektir. Okumayı sevmek kitaba ilgi duymakla başlar. Bu nedenle çocuklara okuma alışkanlığı kazandırma sürecinde kullanılacak kitapların çocukları yaşları, ilgi alanları ve zihinsel gelişim düzeyleri doğrultusunda hazırlanarak onların zihinsel, fiziksel, psikolojik ve duygusal gelişimlerini besleyen çeşitli niteliklere sahip olmaları gerekmektedir. 
Okumayı sevdirmek için, okuma eyleminden alınan doğal zevkin oluşmasına uygun ortam yaratılarak öğrencinin okumaya karşı güdülenmesi sağlanmalı ve bu süreçte öğrenciye gereken fırsat ve zamanın verilmesine özen gösterilmelidir. Okuma eğitimi sürecinde en önemli etkenlerden biri de güdülemedir. Bunun için, okuma eğitimde güdüleyici yöntemlerin kullanılması gereklidir (Sever, 2011: 18). Belki de bu süreçte en önemli konulardan biri, aile ve öğretmenlerin okuma etkinliğini zor ve zevksiz bir iş ve bir ceza şeklinden kolay, eğlenceli bir oyun haline getirmeleridir. Bu noktada öğretmenin kullanacağı aktif öğretim yöntemleri öne çıkmaktadır. Oyunu öğretim sürecinde etkili bir araç olarak kullanan etkileşimli öğretim yöntemlerden biri yaratıcı dramadır.

"Yaratıcı drama, doğaçlama, rol oynama vb. tiyatro ya da drama tekniklerinden yararlanılarak bir grup çalışması içinde, bireylerin bir yaşantıyı, bir olayı, bir fikri, kimi zaman bir soyut kavramı ya da bir davranışı eski bilişsel örüntülerin yeniden düzenlenmesi yoluyla ve gözlem, deneyim, duygu ve yaşantıların gözden geçirildiği oyunsu süreçlerde anlamlandırması, canlandırmasıdır."(San, 2002). Yaratıcı dramada birey bir durumu, duyguyu, düşünceyi anlamlandırıp algıladıklarını bedeni ve sesiyle dışa yansıtmaktadır. "Birey bunu gerçekleştirirken, öğrenme sürecinde, işitme, dokunma, konuşma, dinleme ve düşünme gibi birçok etkinlikte bulunmakta, tüm bedeni ile öğrenme sürecine katılmaktadır. Yaratıcı drama yönteminde birey oyunsu süreçlerle öğrenme sürecine katıldığı için ilgisi, dikkati ve güdülenmesi yüksek olmakta, bunun sonucunda da etkili bir öğrenme süreci gerçekleşmektedir" (Aykaç ve illhan, 2014: 217).

Yaratıcı drama yönteminde oyunlar ve canlandırmalar aracılığılla, ele alınan içeriğin zenginleşmesi ve öğrencilerin içerik hakkında daha ayrıntılı düşünmesi sağlanmaktadır. Yaratıcı drama ile çocuklar oyunun ve öykünün olanakları ile hayallerini oluşturur, sanatın biçimlerini ve yaratıcılıklarını kullanarak hayallerini yeni bir anlatımla yansıtırlar. Bu nedenle yaratıcı drama yöntemiyle gerçekleştirilen yazınsal metin temelli çalışmalarında öykü daha üst düzey bir nitelik kazanarak zenginleşerek gelişir, anlaşılması, yorumlanması ve öğrencilerin anlatılanları somutlaştırması kolaylaşır.

Yaratıcı drama; kişiyi amaca ulaştırma yolunda daha kolay güdüleyen ve harekete geçiren, eğlenceli, akılda kalıcılı̆̆ı arttıran ve bilişsel, duyuşsal ve psikomotor becerilere hitap eden çok yönlü ve aktif bir yöntem olmasından dolayı özellikle ilköğretim dönemi öğrencilerinin oyun temelli çalışmalarla istenen konuya yönlendirilmesini kolaylaştırmaktadır. Bu nedenle kitapla yeni tanışan öğrencilerde kitaba ilişkin olumlu bir algı geliştirerek, okuma isteği uyandırma ve kitabı yaşamlarının bir parçası haline getirme sürecine yumuşak bir geçiş yapmalarını sağlamak açısından yaratıcı dramanın etkili bir yöntem olduğu söylenebilir. Yaratıcı drama atölyesi sürecinde aktif olan çocuğun oyunlar ve canlandırmalar aracılığılla kitaba ilişkin hazırbulunuşluğu artmakta ve karakterlerin rolüne girerek onlarla özdeşim kurması sağlanmakta, kitapta ele alınan bazı dramatik durumları görerek söz 
konusu problemin nasıl çözüleceğine ilişkin düşünce geliştirmekte ve tüm bu etkinliklerle kitaba yaklaşarak kitabı merak etmekte, kitabı okumak istemektedir.

Alan yazın incelendiğinde yaratıcı dramanın her türlü yazınsal metnin (masal, hikâye, şiir, tiyatro, vb.) öğretiminde etkili bir öğretim yöntemi olduğu görülmektedir (Adıgüzel Burgul ve Akfırat, 2014). Çocuk kitaplarıyla ilgili olarak yapılan çalışmaların özellikle masal odaklı olduğu (Çınar, 2006; Sevim, 2006; Layiç, 2008; Özyılmaz, 2008; Akfırat, 2009), masal öğretiminde ve masallarda anlatılanların somutlaştırılmasında yaratıcı drama yönteminin etkili olduğu vurgulanmaktadır. Çocuk edebiyatının gelişimiyle birlikte çocuk kitaplarının yaratıcı drama yöntemiyle ele alınmasına yönelik çalışmalar da artmaktadır. Yılmaz (2008), çalışmasında yaratıcı drama teknikleriyle ele aldığı çocuk kitaplarını yaratıcı düşünme ve sorun çözme aracı olarak kullanılabilecek etkili araçlar olduklarını söylemektedir ve Yılmaz (2009)'a göre öğrencilerin yaratıcı okuma becerilerini geliştirmek için çocuk kitapları yaratıcı drama yöntemiyle birlikte ele alınmalıdır. Aykaç (2011) ile Aykaç ve illhan'ın çalışmalarına (2014) göre, Türkçe öğretiminde çocuk edebiyatı metinleriyle kurgulanan yaratıcı drama etkinliklerinin öğrencilerin konuşma ve anlatma becerilerinin gelişimini olumlu etkilediği belirlenmiştir.

Yazınsal türlerin yaratıcı drama yöntemiyle işlenmesine ilişkin birçok çalışma belirlense de çocuk kitaplarının yaratıcı drama yöntemiyle işlenmesinin öğrencinin okuma sevgisi ve ilgisine ilişkin düşüncesini belirlemeye yönelik bir çalışmanın yapılmadığı görülmüştür. Okuma alışkanlığının kazanılmasında çocukluk döneminin yaşamsal öneminden hareketle çalışma kapsamında yaratıcı drama yöntemiyle ele alınan çocuk kitaplarıyla 8-9 yaş grubu çocuklarda okuma ilgisi ve sevgisi uyandırma üzerinde durulmuştur. Söz konusu yaş grubundaki öğrencilerin okumaya karşı ilgileri ve sevgilerinin geliştirilmesi ve okumaktan zevk almaları sağlanarak okumanın öneminin farkında olan ve okuma alışkanlığına sahip sorgulayan ve merak eden bir nesil yetiştirilebileceği düşünülmektedir.

Bu çalışmanın amacı 3. sınıf öğrencilerinin okuma sevgisi ve ilgisi kazanmasında çocuk kitaplarıyla yaratıcı drama yönteminin kullanılmasına ilişkin görüşlerini belirlemektir. Söz konusu araştırma amacına ulaşmak için "3. sınıf öğrencilerinin çocuk kitaplarıyla okuma sevgisi ve ilgisi kazanmasında yaratıcı drama yönteminin kullanılmasına ilişkin görüşleri nelerdir?" araştırma sorusuna ilişkin olarak aşağıdaki sorulara yanıt aranmıştır:

1. Yaratıcı dramayla gerçekleştirilen okuma etkinliklerinin ardından öğrencilerin okumayı sevme durumlarına ilişkin görüşleri nelerdir?

2. Yaratıcı dramayla gerçekleştirilen okuma etkinliklerinin ardından öğrencilerin kitap okumaktan sıkılma durumlarına ilişkin görüşleri nelerdir? 
3. Yaratıc dramayla gerçekleştirilen okuma etkinliklerinin ardından öğrencilerin boş zamanlarında kitap okuma ya da televizyon seyretme tercihlerine ilişkin görüşleri nelerdir?

4. Yaratıcı dramayla gerçekleştirilen okuma etkinliklerinin ardından öğrencilerin kitap okuma sıklıklarına ilişkin görüşleri nelerdir?

5. Yaratıcı dramayla gerçekleştirilen okuma etkinliklerinin ardından öğrencilerin kitap okumaya yönelik algılarına ilişkin görüşleri nelerdir?

6. Öğrencilerin yaratıcı dramayla gerçekleştirilen kitap okuma atölyelerinde atölye kazanımlarına ulaşma durumları nedir?

\section{Yöntem}

Illkokul 3. sınıf öğrencilerinin okuma sevgisi ve ilgisi kazanmasında yaratıcı drama yönteminin kullanılmasına ilişkin görüşlerini belirlemeyi amaçlayan bu çalışmada nitel araştırma yöntemi kullanılmıştır. "Nitel araştırma, gözlem, görüşme ve doküman analizi gibi nitel veri toplama yönteminin kullanıldığı, algıların ve olayların doğal ortamda gerçekçi ve bütüncül bir biçimde ortaya konmasına yönelik nitel bir sürecin izlendiği araştırma olarak tanımlanabilir" (Yıldırım ve Şimşek, 2013: 45). Nitel yönteme göre insan davranışı esnek ve bir bütün olarak araştırılmalıdır, bu kapsamda süreç ve sürece katılanların tecrübeleri çok önemlidir. Kısacası nitel araştırmalar sürece odaklanarak "neden, nasıl ve niçin" sorularına yanıt aramaktadır (Yıldırım ve Şimsek, 2008). Nitel araştırmanın bazı temel özellikleri ile yaratıcı drama çalışmalarının özellikleri arasındaki ortaklık, nitel araştırma yönteminin yaratııı drama çalışmalarında kullanımını kolaylaştırmaktadır. Nitel araştırmaların temel özellikleri; doğal ortama duyarlılık, araştırmacının katılımcı rolü, bütüncül yaklaşım, algıların ortaya konması, araştırma deseninde esneklik, tümevarımcı analiz ve nitel veridir (Bogdan ve Biklen, 1992; Goetz ve LeCompte, 1984; Patton, 1987; 1990, Akt. Yıldırım ve Şimşek, 2013: 47).

\section{Çalışma Grubu}

Çalışma grubu 2015-2016 öğretim yılı, İzmir ili, Kemalpaşa ilçesinde, bir devlet okuluna devam eden 5 kız ve 4 erkek olmak üzere toplam 9 3.sınıf öğrencisinden oluşmaktadır. Yapılacak çalışma velilere duyurulmuş ve öğrencilerin çalışmaya katılmaları konusunda velilerin izni alınmıştır. Öğrencilerin yaratıcı drama geçmişleri olduğu için uygulamalardan önce grupla tanışmak ve iletişim kurmak amacıyla gerçekleştirilen tanışma, iletişim, uyum ve güven çalışmalarını içeren yaratıcı drama oturumları düzenlenmemiştir. 


\section{Veri Toplama Araçları ve Veri Toplama Süreci}

Çalışma kapsamında ulaşılan veriler; açık uçlu sorulardan oluşan "Okuma İlgisi/isteği Soru Kâğıdı", katılımcılar tarafından gerçekleştirilen her atölyenin sonunda doldurulan "Okuma Günlüğü" ve ders öğretmeni tarafından her atölye çalışması ardından gözlemlerin yazıldığı "Araştırmacı Günlüğü" aracılığıyla elde edilmiştir.

Çalışma öncesinde, öğrencilerin okumaya ilişkin ilgi ve sevgi düzeylerini, okuma sıklıklarını ve okumaya ilişkin algılarını belirlemek üzere açık uçlu beş sorudan oluşan "Okuma İlgisi/Sevgisi Soru Kâğıdı" kullanılmıştır. Uygulama sonunda da aynı soru kâğıdı kullanılarak katııımcıların çalışma öncesi ve sonrasındaki okuma ilgi, sevgi ve algısı arasında bir farkın olup olmadığı incelenmiştir. "Okuma il|gisi/Sevgisi Soru Kâğıdı” nda yer alan sorular; "Kitap okumayı sever misin? Neden?, Hangi sıklıkla kitap okursun?, Kitap okurken sıkılır mısın? Neden?, Boş zamanlarında kitap okumayı mı televizyon seyretmeyi mi tercih edersin? Neden?" şeklindedir.

Çalışma kapsamında, araştırmanın veri çeşitliliğinden faydalanıımış ve geçerliliğini arttırmak amacıyla veri toplama aracı olarak öğrenci “Okuma Günlüğü” ve "Lider Günlüğü" kullanılmıştır. “Okuma Günlüğü” nde yer alan "Bugün ne yaptım?”, "Bugün ne öğrendim?”, "Bugün ne hissettim?”, "Bu kitabı okumak hoşuma gitti, çünkü...", "Bu kitabı okumak hoşuma gitmedi, çünkü..." soruları kapsamında öğrencilerin her atölyeyi ve atölye sürecini değerlendirmeleri sağlanmıştır.

Çalışmada kullanılan diğer veri toplama aracı olan "Lider Günlüğü" nde özellikle sürecin değerlendirmesine ilişkin gözlemler yer almaktadır. Her oturum sonunda lider tarafından öğrencilerin konuya yönelik ilginç tavır ve cevapları, derse katılımları, kitap okuma isteklilikleri, grup çalışmasına katılımları, birbirleriyle iletişimleri gözlemlenerek kaydedilmiştir. Çalışma kapsamında diğer verileri desteklemek ve kazanımlara ulaşma durumunu belirlemek amacıyla kullanılan bir başka veri toplama aracı ise her atölyenin değerlendirme aşamasında öğrenciler tarafından oluşturulan öğrenci ürünleri (resim, gazete, kitap, vb.) ve uygulamalarıdır.

\section{İşlem Basamakları}

Çalışmanın uygulama aşaması 07.04.2016-09.05.2016 tarihleri arasında 4 haftalık süreçte gerçekleştirilmiştir. Yapılan çalışmalar, belirtilen tarihler arasındaki hafta içi günlerde 09.00-11.00 saatleri arasında gerçekleştirilmiştir. Yapılan çalışmalar Türkçe ders kitabı ve öğretim programından bağımsız bir şeklide kurgulanmıştır. Atölyeler çalışma grubunun eğitim gördüğü okulda, sınıf ortamında gerçekleştirilmiştir. Çalışma kapsamında atölye çalışmaları 120 ve 90 dakikalık on bir oturumda gerçekleştirilmiş, toplamda 18 saat 30 dakika uygulama çalışması yapılmıştır. Tüm uygulamalar sınıf öğretmeni (2. araştırmacı) tarafından gerçekleştirildiği için öğrenciler sürece ve 
yönteme alışkındır. Veri analizini kolaylaştırmak ve desteklemek amacıyla tüm uygulamalar kamerayla kayıt altına alınmıştır.

Uygulamaya başlamadan önce öğrencilerin okumaya ilişkin ilgilerini belirlemek amacıyla açık uçlu sorulardan oluşan "Okuma İlgisi/Sevgisi Soru Kâğıdı" kullanılmış ve çalışma sonrasında aynı soru kâğıdı tekrar uygulanmıştır. Her oturumun ardından öğrencilerin o günü günlüklerine yazmaları istenmiş ve lider de ilgili günü kendi günlüğüne değerlendirmiştir.

Gerçekleştirilen on bir oturumun dokuzunda bir çocuk kitabı esas alınmış ve her oturum için belirlenen kitap üzerinden okuma sevgisi ve ilgisi uyandırma kazanımına yönelik olarak yaratıcı drama yönteminin kullanıldı̆ı̆ ders planları hazırlanmıştır. Ders planlarının yapılandırılmasında Adıgüzel (2006) tarafından geliştirilen Isınma/Hazırlık, Canlandırma ve Değerlendirme aşamaları esas alınmıştır (Ek1. Örnek Ders Planı). Isınma/Hazırlık aşamasında konuyla ilgili oyunlar aracılığıyla öğrencilerin kazanıma ilişkin hazırbulunuşluğu geliştirilerek etkinliklerin devamını ve kitabı merak etmeleri sağlanmıştır. Canlandırma aşamasında, öğrencilerin kitaptaki karakterlerin rollerine girerek doğaçlama ve rol oynama gibi tekniklerle kitaplardan hareketle oluşturulan dramatik durumlara çözümler üretmeleri sağlanmıştır. Değerlendirme aşamasında ise tüm çalışmadan edinilen sonuçlar değerlendirilmiş, öğrencilerin kazanıma yani kitap okumaya istek duyarak kitaplarını okuması sağlanmıştır.

Çalışma kapsamında kullanılan kitapların adları ve kısaca içerikleri şu şekildedir:

1. Mış Gibi: -mış gibi resimler çizen Ramon isimli bir çocuğun hayalinden vazgeçmemesiyle başından geçenler hikâye edilmiştir.

2. Palyaçobalığı Palya (Nursel Erdoğan): Palya çevresindeki balıklara komik öyküler anlatan bir palyaçobalığıdır. Bir gün önemli, diğer balıkları da ilgilendiren eski bir hikâyeyi tüm balıklara anlatmak ister ama kimse komik bir şeyler anlatmadığı için onu dinlemez. Hikâyenin devamında Palya ortadan kaybolur ve balıklar onu merak etmeye başlarlar.

3. Flamingo Günlüğü: Nesli tükenen hayvanlarla ilgili ödev hazırlayacak olan Kaan flamingoları seçer. Babası ona bir sürpriz yapar ve flamingoları doğal ortamlarında gözlemleme fırsatı bulur.

4. Okumayı Sevmeyen Çocuğun Hikâyesi: Kitap okumayı sıkıcı bulan Anna'nın düşünceleri, kütüphanede bulduğu kitaptan sonra değişir. Hayal bile edemediği şeyler başına gelir.

5. Yazmayı Sevmeyen Çocuğun Hikâyesi: Yazmayı sevmeyen Samuel'in sihirli bir kalem yardımıyla ne kadar güzel hikâyeler yazdığının farkına varması hikâye edilmiştir. 
6. Defne Ağacı ve Orman Kardeşliği: Ömer Faruk tarafından yazılan bu kitapta çevre kirliliğinin yarattığı sonuçlar ve onlara itiraz eden hayvanların ve ağaçların heyecanlı maceraları anlatiliyor.

7. Kitaplardan Korkan Çocuk: Küçük Leopold, daha sekiz yaşındadır ve kitaplardan çok korkmaktadır. Her yıl doğum gününde istediği hediye değil de kitap alınmaktadır. Bu durumdan sıkılan Leopold çareyi evden kaçmakta bulur.

8. Doğumgünü Hediyesi: Behiç Ak tarafından resimlenen bu kitapta herhangi bir yazı bulunmamaktadır. Doğum gününde hediye alan bir çocuğun, hediye paketini açma çabası ve sonunda aldığı hediyeyi konu alan bir kitaptır.

9. Bozuk Müzik Kutusu: Fırıncı Fer oğlu için bir hediye almak istiyormuş. Ancak karşısına çıkan tek şey bozuk bir müzik kutusu olmuş. Bu müzik kutusunun oğlunun uyku problemine çare olacağını düşünen fırıncı, kutuyu tamir etmeye karar vermiş.

\section{Verilerin Analizi}

Verilerin toplama aracı olarak kullanılan “Okuma ilgisi/Sevgisi Soru Kâğıdı”, “Okuma Günlüğü” ve "Lider Günlüğü" nden ulaşılan her türlü yazılı materyalin analizinde betimsel analiz kullanılmıştır. Betimsel analize göre, elde edilen veriler çoğunlukla alan yazından belirlenen temalara göre özetlenip yorumlanarak doğrudan alıntılarla katılımcıların görüşlerine yer verilir (Yıldırım ve Şimşek, 2008, s.224). Öğrenci değerlendirmeleri ve kazanımlara ulaşma düzeylerine belirlemek amacıyla kamera kayıtları da belirlenen bulgu başıkları kapsamında yeniden incelenerek lider günlüğüne ilişkin veri analizini desteklemiştir. Çalışma kapsamında ulaşılan veriler, araştırmanın alt problemlerinde yer alan sorular doğrultusunda özetlenip yorumlanmış ve katılımcı görüşlerinden doğrudan alıntılarla sunulmuştur.

\section{Bulgular ve Yorum}

Çalışmanın bu bölümünde, veri toplama araçları aracılığıyla ulaşılan veriler "Öğrencilerin Okuma Illgi ve Sevgilerine İlişkin Bulgular" ve "Atölye Kazanımlarına ilişkin Bulgular" olmak üzere iki alt başlık altında değerlendirilmiştir. İlk üç alt probleme ilişkin bulgular "Öğrencilerin Okuma illgi ve Sevgilerine İlişkin Bulgular" başlığı altında ele alınmış, dördüncü alt probleme ilişkin bulgular ise "Atölye Kazanımlarına Illişkin Bulgular" başlığı altında incelenmiştir.

Öğrencilerin okuma ilgi ve sevgilerine ilişkin bulgular

Öğrencilerin kitap okumayı sevip sevmeme durumlarını ve nedenlerini belirlemek üzere çalışma öncesinde ve sonrasında katılımcılara "Okuma ilgisi/Sevgisi Soru Kâğıdı" verilmiştir. "Okuma 
i̇lgisi/Sevgisi Soru Kâğıdı"nda öğrencilerin okumayı sevme durumu, okumaktan sıkılma durumu, okuma sıklıkları, televizyona tercih durumları ve okuma algılarına ilişkin beş soru yer almaktadır.

Soru kâğıdında öğrencilerin okumayı sevip sevmeme durumları ve nedenlerini belirlemek amacıyla onlara "Kitap okumayı sever misiniz? Neden?" sorusuna yer verilmiştir. Öğrencilerin çalışma öncesinde ve sonrasında bu soruya verdikleri yanıtlar Tablo 1'de gösterilmiştir.

Tablo1. Öğrencilerin Kitap Okumayı Sevme Durumları

\begin{tabular}{|c|c|c|}
\hline \multicolumn{3}{|c|}{ Kitap okumayı sever misin? Neden? } \\
\hline Ugrencl & & \\
\hline & Çalışma Öncesi & Çalışma Sonrası \\
\hline Ö1 & Severim. Çünkü eğlencelidir. & $\begin{array}{l}\text { Evet. İçinde resim ve yazılar olduğu için } \\
\text { severim. }\end{array}$ \\
\hline Ö2 & Severim. Çünkü eğlencelidir. & Evet. Kitap insana iyi şeyler öğretir \\
\hline Ö3 & $\begin{array}{l}\text { Severim. Çünkü öğreneceğim çok } \\
\text { bilgi var. }\end{array}$ & Severim. Kitap çok güzel. \\
\hline Ö4 & $\begin{array}{l}\text { Severim. Çünkü güzel hikâyeler } \\
\text { vardır. }\end{array}$ & Evet. Bilmediğim şeyleri öğrenirim. \\
\hline Ö5 & Biraz severim. Çünkü çabuk sıkılırım. & Evet. Çok güzel maceralar var. \\
\hline Ö6 & Severim. Çünkü zekâm gelişir. & Severim. Çünkü kafamda canlandırırım. \\
\hline Ö7 & $\begin{array}{l}\text { Severim. Çünkü hayal gücümü } \\
\text { canlandırır. }\end{array}$ & Evet. Çünkü çok heyecanlıdır her şey. \\
\hline Ö8 & $\begin{array}{l}\text { Severim. Resimleri eğlenceli olduğu } \\
\text { için. }\end{array}$ & Evet. Kitap okudukça kafamda canlanıyor. \\
\hline Ö9 & $\begin{array}{l}\text { Evet. Çünkü okuduğum zaman } \\
\text { kitabın içindeymişim gibi geliyor. }\end{array}$ & $\begin{array}{l}\text { Severim. Kitaptaki hikâyeler ve resimler } \\
\text { güzel. }\end{array}$ \\
\hline
\end{tabular}

Tablo 1'e göre öğrencilerden sekizinin okumayı sevdiği, sadece birinin (Ö5) biraz sevdiği görülmektedir. Çalışma sonunda çabuk sıkıldığı için biraz severim yanıtını veren öğrencinin artık kitap okumayı sevdiği ve sıkılmadığı, çünkü kitapta güzel maceralar olduğunu düşündüğü görülmektedir. Resimleri eğlenceli olduğu için kitabı sevdiğini belirten Ö8 ile zekâsı gelişeceği için kitabı sevdiğini belirten Ö6, çalışma sonunda kitap okudukça kafalarında canlandığı için sevdiklerini belirtmişlerdir. Atölye sürecinde gerçekleştirilen canlandırma çalışmaları ve çeşitli etkinliklerin ardından öğrencilerin ezberlenmiş yanıtlardan uzaklaşarak daha samimi yanıtlar verdikleri düşünülmektedir. Kitaplarda anlatılan hikâyelerin soyut olması öğrencilerin anlatılanları somutlaştırması oldukça güçtür ancak atölye çalışmalarının ardından öğrencilerden bazılarının anlatılanları kafalarında canlandırabildikleri yani somutlaştırabildikleri belirlenmiştir.

Öğrencilerin çalışma öncesinde verdikleri "severim" yanıtlarının gerekçeleri; eğlenceli olması, bilgi vermesi, zekâ geliştirmesi, resimlerinin, hayal gücünü canlandırması olarak görülür. Çalışma sonundaki gerekçeler; öğrencilerin kitabı kafalarında canlandırabilmeleri, çok heyecanlı olması ve içinde macera olması, resimlerin güzel olması ve bir şeyler öğretmesi olarak belirtilmiştir. Öğrencilerin çalışma öncesi ve sonrasında kitabı sevme durumlarına ilişkin verdikleri yanıtlar aynı olsa da gerekçeler incelendiğinde, öğrencilerin atölye çalışmalarının ardından öğrenilmiş gerekçeler yerine 
daha kişisel gerekçeler sunarak kitabı kafalarında canlandırabildikleri, kitapların heyecanlı olduğunu düşündükleri ve güzel maceralar içerdiği için sevdiklerini belirttikleri düşünülmektedir.

Soru kâğıdında öğrencilerin kitap okurken sıkılma durumları ve nedenlerini belirlemek amacıyla "Kitap okurken sıkılır mısınız? Neden?” sorusuna yer verilmiştir. Öğrencilerin çalışma öncesinde ve sonrasında bu soruya verdikleri yanıtlar Tablo 2'de gösterilmiştir.

Tablo 2. Öğrencilerin Kitap Okurken Sıkılma Durumları

\section{Kitap okurken sıkılır mısın? Neden?}

\begin{tabular}{|c|c|c|}
\hline Öğrenci & Çalışma Öncesi & Çalışma Sonrası \\
\hline Ö1 & $\begin{array}{l}\text { Bazen sıkılıyorum. Çünkü anlamadığım } \\
\text { kelime oluyor. }\end{array}$ & $\begin{array}{l}\text { Sıkılmam ama hikâyeyi beğenmezsem } \\
\text { sıkılırım. }\end{array}$ \\
\hline Ö2 & Evet sıkılırım. Çünkü okurken uzun geliyor. & $\begin{array}{l}\text { Sıkılmam. Kitabı çok seviyorum. Okudukça } \\
\text { okuyası geliyor insanın. }\end{array}$ \\
\hline Ö3 & $\begin{array}{l}\text { Bazen sıkılırım. Çünkü anlamadığım } \\
\text { kelimeler olabiliyor. }\end{array}$ & Biraz. Kitabın bazı yerleri sıkıcı gelebiliyor. \\
\hline Ö4 & $\begin{array}{l}\text { Evet sıkılırım. Çünkü hikâyeler çok uzun } \\
\text { geliyor. }\end{array}$ & Sıkılırım. Eğlenceli olmadığında sıkılırım. \\
\hline Ö5 & $\begin{array}{l}\text { Biraz sıkılırım. Bazı kitapların bölümlerini } \\
\text { beğenmiyorum. }\end{array}$ & $\begin{array}{l}\text { Biraz. Çünkü çok uzun cümleleri okurken } \\
\text { sıkılıyorum. }\end{array}$ \\
\hline Ö6 & Bazen sıkılırım. Çünkü çok anlamıyorum. & Sıkılmam. Kitap okumaya dalarım. \\
\hline Ö7 & $\begin{array}{l}\text { Hayır sıkılmam. Çünkü kitap okumak } \\
\text { heyecanlıdır. }\end{array}$ & Hayır. Okumak heyecanlı geliyor. \\
\hline Ö8 & $\begin{array}{l}\text { Bazen sıkılırım. Kitap içindeki farklı } \\
\text { hikâyelerin çabuk bitmesi beni sıkar. }\end{array}$ & $\begin{array}{l}\text { Sıkılmam. Kitaplarım tam benim istediğim } \\
\text { gibi. }\end{array}$ \\
\hline Ö9 & $\begin{array}{l}\text { Bazen sıkılırım. Çünkü } \quad \text { kitapta resim } \\
\begin{array}{l}\text { olmadığı } \\
\text { canlandıramınorum. }\end{array}\end{array}$ & $\begin{array}{l}\text { Hayır. Kitabın içindeymişim gibi hayal } \\
\text { ettiğimde sıkılmıyorum. }\end{array}$ \\
\hline
\end{tabular}

Tablo 2'ye göre öğrencilerden altısı bazen, ikisi ise hep kitap okurken sıkıldığını, biri sıkılmadığını belirtmektedir. Öğrencilerin sıkılma nedenleri; anlaşılmayan kelimeler, kitabın uzun olması ve resim olmaması olarak gösterilmiştir. Çalışma sonunda ise öğrencilerden altısı sıkılmadığını, ikisi biraz sıkıldığını belirtmiştir. Çalışma öncesinde Ö2'nin “Evet sıkılırım. Çünkü okurken uzun geliyor." olan görüşleri çalışma sonunda "Sıkılmam. Kitabı çok seviyorum, okudukça okuyası geliyor insanın." şeklinde değişmiştir. Görüşlerini "Bazen sıkılıım. Çünkü anlamıyorum." şeklinde ifade eden Ö6, çalışma sonrasında "Sıkılmam. Kitap okumaya dalarım." demiştir. Ö9 ise çalışma öncesinde "Bazen sıkılırım. Çünkü kitapta resim olmadığı zaman kafamda canlandıramıyorum." derken çalışma sonunda "Hayır, kitabın içindeymişim gibi hayal ettiğimde sıkılmıyorum." görüşleriyle artık okumaktan sıkılmadığını belirtmiştir. Öğrenci görüşleri değerlendirildiğinde yaratıcı dramayla gerçekleştirilen okuma etkinliklerinin öğrencilerin metni daha kolay anlamalarına, metnin içine kendini kaptırmalarına ve kendilerini kitabın içindeymiş gibi hayal etmelerine yardımcı olduğu düşünülmektedir. Bu nedenle yaratıcı drama çalışmalarıyla gerçekleştirilen okuma etkinliklerinin öğrencilerin büyük bölümünün kitap okumaktan sıkılmamasını sağladığı söylenebilir. 
Öğrencilerin kitap okumaya ilişkin ilgi ve alışkanlıklarını belirlemek amacıyla onlara "Boş zamanlarında kitap okumayı mı televizyon seyretmeyi mi tercih edersin? Neden?" sorusu sorulmuştur. Öğrencilerin çalışma öncesinde ve sonrasında bu soruya verdikleri yanıtlar Tablo 3'te gösterilmiştir.

Tablo 3. Öğrencilerin Boş Zamanlarında Kitap Okuma ya da Televizyon Seyretme Tercihleri

Boş zamanlarında kitap okumayı mı televizyon seyretmeyi mi tercih edersin? Neden?

\begin{tabular}{|c|c|c|}
\hline Öğrenci & Çalışma Öncesi & Çalışma Sonrası \\
\hline Ö1 & $\begin{array}{l}\text { Televizyonu tercih ederim. Çünkü daha eğlenceli } \\
\text { şeyler var. }\end{array}$ & $\begin{array}{l}\text { Televizyon. Çünkü kitapta insanları } \\
\text { canlandıramıyorum }\end{array}$ \\
\hline 0̈2 & $\begin{array}{l}\text { Televizyonu tercih ederim. Çünkü çizgi filmler daha } \\
\text { eğlencelidir. }\end{array}$ & $\begin{array}{l}\text { Kitap okumayı. Çünkü kitap çok iyi } \\
\text { bir şeydir. }\end{array}$ \\
\hline Ö3 & $\begin{array}{l}\text { Televizyon. Çizgi filmler var ama o çizgi filmin kitabı } \\
\text { olsaydı onu seçerdim. }\end{array}$ & Televizyon. Çünkü çizgi film var. \\
\hline Ö4 & Televizyon izlerim. Çünkü dinlemek kolayıma geliyor. & Televizyon. Çünkü ilginç şeyler var. \\
\hline Ö5 & $\begin{array}{l}\text { Bilgisayar oynamayı tercih ederim. Çünkü kitap } \\
\text { okumak biraz sıkıcıdır. }\end{array}$ & $\begin{array}{l}\text { Televizyon. Çünkü en sevdiğim film } \\
\text { var. }\end{array}$ \\
\hline 0̈6 & Televizyonu tercih ederim. Çünkü eğlencelidir. & $\begin{array}{l}\text { Televizyonu seçerim. Kitap okumak } \\
\text { sıkabiliyor. }\end{array}$ \\
\hline ö7 & $\begin{array}{l}\text { Televizyona bakarım. Kafamdakileri atmak için } \\
\text { televizyon izlerim. }\end{array}$ & $\begin{array}{l}\text { Televizyon. Çünkü düşmanlar } \\
\text { gelecek mi diye? }\end{array}$ \\
\hline 0̈8 & Televizyon izlerim. Çünkü daha güzel çizgi filmler var. & $\begin{array}{l}\text { Kitap okumayı tercih ederim. Çünkü } \\
\text { kitap okursam çalışkan olurum. }\end{array}$ \\
\hline ö9 & $\begin{array}{l}\text { İkisini de tercih ederim ama en çok televizyon } \\
\text { izlerim. Çünkü sevdiğim çizgi filmler daha eğlenceli. }\end{array}$ & $\begin{array}{l}\text { Kitap. Çünkü okuyunca meslek } \\
\text { sahibi oluruz. }\end{array}$ \\
\hline
\end{tabular}

Tablo 3 incelendiğinde, öğrencilerden sekizinin televizyon seyretmeyi, birinin (Ö5) ise tercihler arasında yer almasa da bilgisayar oynamayı tercih ettiği görülmektedir. Öğrencilerin televizyonu tercih etme nedenleri; televizyonda çizgi filmlerin olması (Ö2, Ö3, Ö8, Ö9), televizyonun eğlenceli olması (Ö1, Ö6) ve dinlemenin daha kolay olması (Ö4) olarak belirtilmiştir. Çalışma sonunda öğrencilerden üçünün (Ö2, Ö8, Ö9) televizyon yerine kitabı tercih ettikleri görülmektedir. Öğrencilerin kitabı tercih etme nedenleri; kitabın iyi bir şey olması, çalışkan olmayı sağlaması ve meslek sahibi olmayı sağlaması olarak belirtilmiştir. Öğrencilerin özellikle çizgi filmler gibi görsel yardımcılar nedeniyle televizyonu tercih etmesi, bu yaş grubuna tavsiye edilecek kitapların da görsel ağırlıklı olması gerektiğini düşündürmektedir. Yaratıcı drama çalışmalarıyla gerçekleştirilen okuma etkinliklerinin öğrencilerin az bir kısmının boş zaman etkinliği tercihini etkilediği söylenebilir.

Öğrencilerin kitap okuma sıklıklarını belirlemek amacıyla onlara "Hangi sıklıkla kitap okursun?" sorusu sorulmuştur. Öğrencilerin çalışma öncesinde ve sonrasında bu soruya verdikleri yanıtlar Tablo 4'te gösterilmiştir. 


\begin{tabular}{lll}
\hline \multicolumn{3}{c}{ Hangi sıklıkla kitap okursun? } \\
\hline Öğrenci & Çalışma Öncesi & \multicolumn{1}{c}{ Çalışma Sonrası } \\
Ö1 & $\begin{array}{l}\text { Canım istediği zaman, arada sırada } \\
\text { okurum }\end{array}$ & Bazen okurum. \\
Ö2 & Haftada bir gün kitap okurum. & Arada sırada \\
Ö3 & Haftada bir gün bir tane okurum. & Haftada 2-3 kez. \\
Ö4 & Arada sırada, canım istediğinde & Haftada iki gün ama hep değil. \\
Ö5 & okuyorum. & Haftada bir gün o da bazen. \\
Ö6 & Sadece cumartesi günleri okurum. & Haftada bir gün veya aklıma geldiğinde \\
Ö7 & Haftada iki ya da üç kez okurum. & iki günde bir. \\
Ö8 & Arada sırada okurum. & Haftada bir. \\
Ö9 & Iki günde bir okuyorum. & Haftada bir-iki gün. \\
\hline
\end{tabular}

Tablo 4' göre çalışma öncesindeki yanıtlar incelendiğinde öğrencilerin özellikle arada sırada kitap okurum ifadesini sıklıkla (Ö1, Ö4, Ö6, Ö8) kullandıkları, üç öğrencinin (Ö2, Ö3, Ö5) haftada bir, iki öğrencinin $(O ̈ 7$, Ö9) de iki ya da üç kez okuduğunu belirttiği görülmektedir. Öğrencilerin yanıtları, belirli bir okuma rutinlerinin olmadığını, düzenli ve sık kitap okumadıklarını göstermektedir. Çalışma sonunda iki öğrencinin (Ö1, Ö2) arada sırada okuduğu, üç öğrencinin (Ö5, Ö6, Ö8) haftada bir, üç öğrencinin (Ö4, Ö7, Ö9) de haftada iki ya da üç kez kitap okuduklarını belirttikleri görülür. Söz konusu yanıtların atölye çalışmaları sürecinde düzenli olarak kitap okumasıyla ilgili olduğu düşünülmekle birlikte yaratıcı drama çalışmalarının öğrencilerin okuma sıklığını geliştirdiği ya da daha düzenli bir şekilde yürütmelerini desteklediği yönündedir.

Öğrencilerin kitap okumaya ilişkin algılarını belirlemek amacıyla onlara "Kitap okumayı bir şeye benzetsen neye benzetirsin? Neden?" sorusu sorulmuştur. Öğrencilerin çalışma öncesinde ve sonrasında bu soruya verdikleri yanıtlar Tablo 5'de gösterilmiştir.

Tablo 5. Öğrencilerin Kitap Okumaya ilişskin Algıları

\section{Kitap okumayı bir şeye benzetsen neye benzetirsin? Neden?}

\begin{tabular}{|c|c|c|}
\hline Öğrenci & Çalışma Öncesi & Çalışma Sonrası \\
\hline Ö1 & $\begin{array}{l}\text { Sözlüğe benzetirim. Çünkü içinden bilgi } \\
\text { alırız. }\end{array}$ & $\begin{array}{l}\text { Televizyona benzer. Çünkü kitapta da } \\
\text { televizyondaki gibi resimler var. }\end{array}$ \\
\hline Ö2 & Maceraya benzer. Çünkü eğlencelidir. & $\begin{array}{l}\text { Bilgisayara benzer. Çünkü ikisinde de resim } \\
\text { var. }\end{array}$ \\
\hline Ö3 & $\begin{array}{l}\text { Çizgi filme benzer. Kafamda canlandırdığım } \\
\text { zaman çizgi film gibi oluyor. }\end{array}$ & $\begin{array}{l}\text { Çizgi filme benzetiyorum. Çünkü kitaptaki } \\
\text { resimler sayfa sayfa geçiyor. }\end{array}$ \\
\hline Ö4 & Masaya benzer. Çünkü uykumu getirir. & $\begin{array}{l}\text { Arabaya benzetirim. Çünkü kitabın içinde } \\
\text { araba varsa arabaya benzetirim. }\end{array}$ \\
\hline Ö5 & Hayale benzer. Çünkü kafamda canlanıyor. & $\begin{array}{l}\text { Hayale benzer. Çünkü okurken kitaba } \\
\text { dalıyorsun. }\end{array}$ \\
\hline Ö6 & $\begin{array}{l}\text { Hayvanlara benzer. Çünkü kitapların içinde } \\
\text { hayvanlar var. }\end{array}$ & $\begin{array}{l}\text { Televizyona benzer. Televizyonda hikâye } \\
\text { yazıyorum, okuyorum. }\end{array}$ \\
\hline Ö7 & $\begin{array}{l}\text { Oyun oynamak gibidir. Çünkü kitap okumak } \\
\text { ve oyun oynamak güzeldir. }\end{array}$ & Maceraya benzer. Çünkü gezmeyi severim. \\
\hline Ö8 & Telefona benzer. İçinde oyunlar var. & Televizyon gibidir. Çünkü televizyonda da \\
\hline
\end{tabular}




\begin{tabular}{lll}
\hline & kitapta da resimler olur. & \\
Ö9 & & gual kurmak gibidir. Çünkü hayal kurarak \\
okumak eğlencelidir. & $\begin{array}{l}\text { Televizyon gibidir. Çünkü kamda } \\
\text { canlandırdığımda televizyon izler gibi } \\
\text { oluyorum. }\end{array}$ \\
\hline
\end{tabular}

Tablo 5’e göre öğrencilerin çalışma öncesinde kitap okumayı benzettikleri kavramlar; sözlük, macera, çizgi film, masa, hayal, telefondur. Bilgi vermesi yönüyle sözlüğe benzetilen kitap (Ö1), oyun gibi olduğu için telefona benzetilmiş(Ö7, Ö8), kafada canlandığı için çizgi film (Ö3) ve hayale (Ö5) benzetilmiş, eğlenceli olduğu için macera (Ö2) ve hayale (Ö9) benzetilmiş, uyku getirdiği için masaya (Ö4) benzetilmiştir. Çalışma sonunda kitap okumanın benzetildiği kavramlar; televizyon (Ö1, Ö6, Ö8, Ö9), bilgisayar (Ö2), çizgi film (Ö3), araba (Ö4), hayal (Ö5), macera (Ö7) şeklindedir. Öğrencilerin çoğunluğunun kitap okumayı bir görselle birleştirmeleri ve resimleri olduğu için televizyon, bilgisayar, çizgi filme benzetmeleri dikkat çekmektedir. Bir önceki soruda kitap okumak yerine televizyon sevmeyi tercih ettiğini belirten öğrencilerin çalışma sonunda kitap okumayı televizyon seyretmeye benzetmeleri kitap okumaya ilişkin algılarının ve ilgilerinin geliştiğini düşündürmektedir. Yaratıcı drama ile gerçekleştirilen okuma etkinliklerinin çocukların okuma algısı, ilgisi ve sevgisini geliştirmede etkili bir başlangıç olarak kullanılabileceği ancak bu ilgi ve sevginin tam olarak yerleşebilmesi için belirli aralıklarla devam etmesi gerektiği düşünülmektedir.

Atölye kazanımlarına ilişkin bulgular

Öğrencilerin kitap okumaya karşı ilgi ve sevgilerin arttırmak amacıyla gerçekleştirilen bu çalışma kapsamında on bir atölye gerçekleştirilmiştir. Kazanımlara ilişkin bulgular kapsamında öğrencilerin kazanımlara ulaşma durumları; okuma günlüklerinden ve lider günlüğünden elde edilen veriler ile atölye sonu değerlendirme etkinliklerinin analizi ile elde edilmiştir. Her atölye, okuma günlüğünde yer alan "Bugün ne yaptım?”, "Bugün ne öğrendim?”, "Bugün ne hissettim?”, "Bu kitabı okumak hoşuma gitti, çünkü...", "Bu kitabı okumak hoşuma gitmedi, çünkü..." soruları kapsamında analiz edilerek öğrencilerin kazanımlara ulaşma durumu değerlendirilmiştir. Okuma günlüğüne dayalı olarak gerçekleştirilen değerlendirmeleri desteklemek ve veri çeşitliliğin arttırmak amacıyla bazı atölyelerde atölye değerlendirme etkinlik materyalleri (gazete, resim, vb.), atölye sonu değerlendirme formu ve araştırmacı günlüğünden yararlanılmıştır.

\section{Birinci atölyenin kazanımları}

"Kitap okumaya karşı ilgi duyar." ve "Kitabın içeriği hakkında çıkarımlarda bulunur." biçiminde ifade edilmiştir. Atölye sonunda yazılan okuma günlüğünde öğrencilerin ne öğrendiklerine ilişkin verdikleri yanıtlar değerlendirildiğinde, öğrencilerden dördünün (Ö1, Ö5, Ö6, Ö9) ağacı ve kitabı korumayı öğrendikleri ve kitabın çok yararlı olduğunu düşündükleri belirlenmiştir. Ö1'in bu konudaki görüşleri "Kitabı korumayı öğrendim.", Ö9’un görüşleri "Kitapların çok yararlı olduğunu öğrendim." şeklindedir. Bazı öğrenciler (Ö7, Ö8, Ö3) özellikle süreçte gerçekleştirilen etkinliklerden 
çok hoşlandıklarını; gazete yazmayı, canlandırma yapmayı ve oyun oynamayı öğrendiklerini belirtmişlerdir. Öğrencilerin gazete çıkarma etkinliğine olumlu katılımları ve eğlenerek sürece katılmaları lider günlüğünde şu şekilde belirtilmiştir "Gazete okunmayan bir köyde gazete haberi oluşturmalarını beklemek zorlanmalarına sebep olmuştu fakat verdiğim örnekler ve yönlendirmelerimle ortaya güzel ürünler çıtı."(07.04.2016). Atölyenin değerlendirme etkinliği olarak gerçekleştirilen gazete çalışması incelendiğinde, Kitap Canavarı ile yapılan röportaj sonucu hazırlanan gazetede kazanımla ilgili olarak kitap canavarının ağzından, gazetede kitabın yararı ve öneminden bahsedilmesi öğrencilerin kitap içeriğine ilişkin çıkarımda bulunduklarını göstermektedir. Çalışma sonunda ne düşündükleri sorulan öğrencilerden üçü (Ö3, Ö5, Ö6, Ö8) kitap canavarını ve onun yaşadıklarını düşündüklerini belirtmektedirler. Öğrenci görüşleri şu şekildedir: "Kitap canavarının önceden hiç kitap okumadığını düşündüm."(Ö3), “Kitap canavarını önce kötü sonra iyi düşündüm."(Ö5), "Kitap canavarının neden kitap çaldığını düşündüm."(Ö8). Öğrencilerin oluşturduğu gazeteler ve düşünceleri göz önünde bulundurulduğunda öğrencilerin çoğunluğunun kitabın içeriği hakkında çıkarımda bulunur kazanımına ulaştıkları düşünülmektedir.

\section{ikinci atölyenin kazanımları}

"Kitap okumaya karşı ilgi duyar." ve "Kitabın içeriği hakkında çıkarımlarda bulunur." olarak ifade edilmiştir. Okuma günlükleri değerlendirildiğinde öğrencilerden beşi (Ö2, Ö3, Ö4, Ö6) kitabın kahramanının hayatını ve resimlerini öğrendiklerini şu cümlelerle belirtmektedirler: "Ramon'un resmini öğrendim." (Ö2), “Ramon'un hayatını öğrendim.”(Ö3), “Ramon'un hikâyesini öğrendim.”(Ö4), “Ramon'un resimlerini öğrendim.” (Ö6). Atölye sürecinde gerçekleştirilen resim etkinliğinden dolayı öğrencilerden Ö7 "Ressam olmayı öğrendim.", şiir etkinliğinden dolayı da Ö8 "Şiir yazmayı öğrendim." görüşlerini belirtmişlerdir. Öğrencilerden üçü (Ö1, Ö5, Ö9) ise süreçte gerçekleştirilen oyunları öğrendiklerini belirtmişlerdir. "Eğlenceli oyunlar öğrendim.”(Ö1, Ö5, Ö9). Atölye sonundaki düşünceleri sorulduğunda öğrencilerden yedisinin (Ö2, Ö3, Ö4, Ö5, Ö6, Ö7, Ö9) Ramon'u, hayatını, okulunu, ve hikâyesini düşündükleri ve onunla empati kurarak yaşadıklarına üzüldükleri öğrenilmiştir. Bu görüşlerden bazıları: "Ramonun hikâyesini düşündüm."(Ö4), Ramon’a biraz üzüldüm".(Ö5), “Ramon'un hayatını düşündüm.”(Ö7) şeklindedir. Öğrencilerin kitabın kahramanının hayatını, okulunu, hikâyesini düşünmeleri onların kitaba karşı ilgi duyduklarını düşündürmektedir. Okuma günlüğünde öğrencilerin hepsinin bu kitabı okumak hoşuma gitti yanıtını vermesi onların bu kitabı okumaya karşı ilgi duyduklarının bir göstergesidir. Öğrencilerden Ö1 yapılan etkinliklerden dolayı bu kitabı okumanın hoşuna gittiğini "Çok eğlenceli şeyler yaptık." belirtirken, Ö2, Ö3, Ö4, Ö9 ise kitabın resimleri ve çok olduğu için bu kitabı okumanın hoşlarına gittiğini belirtmişlerdir. Bu görüşlerden bazıları şöyledir: "Ramon'un kitabında resim olduğu için çok beğendim." (Ö2), "Resimleri güzel bir kitaptı." (Ö9). Öğrencilerden bazıları (Ö5, Ö7) kitabın heyecanlı ve komik olduğu için bazıları (Ö8) ise 
eğlenceli olduğu için hoşlarına gittiğini belirtmişlerdir. Öğrencilerin kitaba karşı tavrına ilişkin lider günlüğünde belirtilen şu ifade öğrencilerin ilgisini göstermektedir: "Canlandırmalardan sonra okuyacakları kitabı ilk kez gösterdiğimde şaşırdılar. Sanırım bunun da etkisi ile kitabı bir solukta okudular."(8.04.2016). Öğrencilerin kahraman ve kitabın hikâyesi üzerinden gerçekleştirdikleri değerlendirmelerden hareketle öğrencilerin çoğunun kitaba ilgi duyduğu ve kitabın konusuna ilişkin çıkarımda bulunduğu söylenebilir.

\section{Üçüncü atölyenin kazanımları}

“Her kitabın farklı bilgiler içerdiğini söyler." ve "Farklı türdeki kitaplar hakkında öğrendiklerini yazar." olarak belirtilmiştir. Okuma günlükleri değerlendirildiğinde öğrencilerden ikisinin (Ö2, Ö3) roman, çizgi roman ve çocuk dergisini öğrendiğini belirttiği görülür. Öğrencilerden beşi ise kitap okumanın önemi ve güzel olduğuna ilişkin görüşlerini belirtmişlerdir. Bu konudaki görüşleri: "Sıkıldığımda kitabı bırakmamayı öğrendim."(Ö1), "Kitapların zevkli olduğunu öğrendim." (Ö4), "Kitap okumanın çok güzel bir şey olduğunu öğrendim." (Ö5), "Kitabı sevmeyi öğrendim.”(Ö7). Öğrencilerin düşünceleri incelendiğinde; birinin (Ö7) kitabı ne zaman okuyacağını düşündüğü, birinin (Ö8) çizgi romanı, birinin (Ö9) dramanın ne kadar güzel olduğunu, (Ö4) kitapları ve kitap kapmaca oyununu yazdığı görülmektedir. Atölye kapsamında gerçekleştirilen değerlendirme etkinliğinde yazılan notlar incelendiğinde öğrencilerin farklı türler hakkında öğrendiklerini yazdıkları ve her kitabın farklı bilgi içerdiğini fark ettikleri görülmüştür. Okuma günlüğünde öğrencilerin tümünün kitabı okumak hoşuma gitti yanıtını vermesi onların bu kitabı okumaya karşı ilgi duyduklarını göstermektedir. Lider günlüğünde üçüncü atölye kazanımına ilişkin şu notlar alınmıştır: "ilk iki atölyeye göre konu ve kazanım ile ilgili dönüt almakta atölyenin başında zorlanmama rağmen sonuna doğru aldığım dönütler kazanıma ulaşmamı sağladı."(11.04.2016)

\section{Dördüncü oturumun kazanımları}

"Kitap okumaya istek duyar.", "Hikâyedeki anahtar kelimelerden yola çıkarak resim yapar." ve "Balıklar ve bazı deniz canlılarına ilişkin farkındalık kazanır." şeklinde belirtilmiştir. Okuma günlüğünde belirtilenlere göre öğrencilerden yedisi balık ve deniz canlıları ile ilgili birbirlerinden farklı farkındalıklara ulaşmışlardır. Öğrencilerin öğrendiklerini belirttikleri konular şöyledir: Ö1 "Mercanları korumayı öğrendim.", Ö3 "Balıkları ve denizi korumayı öğrendim.", Ö4 "Balıklar mercanlara yuva yaparlarmış.", Ö5 “Balıkların renginin farklı olduğunu”, Ö6 "Balık türlerini öğrendim.”, Ö8 “Mercanları öğrendim.", Ö9 "Mercanların canlı olduğunu öğrendim.." Öğrencilerin tümü bu kitabı okumanın hoşlarına gittiğini belirtmiştir. Öğrencilerden dördü (Ö2, Ö3, Ö4, Ö6) kitaptan hoşlanma nedeni olarak kitapta balıklardan bahsedilmesi nedenini şu şekilde belirtmişlerdir: "Çok fazla balık türü olması ilgimi çekti." (Ö3), "Balıklardan bahsedilmesi hoşuma gitti." (Ö4). Öğrenci görüşleri değerlendirildiğinde 
öğrencilerin deniz canlılarına ilişkin farkındalık kazandıkları ve kitabı okumaya istek duyarak ilgiyle okudukları belirlenmiştir.

\section{Beşinci atölyenin kazanımları}

"Kendi kitabını oluşturur.", Resimlerden yola çıkarak hikâye yazar.", "Kitap kapağı tasarlar.", "Kitabın yapım ve yazım aşaması hakkında fikir sahibi olur." olarak ifade edilmiştir. Öğrencilerden yedisi (Ö1, Ö4, Ö5, Ö6, Ö7, Ö8, Ö9) kitap yapmayı öğrendiğini belirtir, bu durum şu cümleyle örneklenebilir "Elimizdeki malzemelerle kitap yapabileceğimizi öğrendim."(Ö9). Öğrencilerin düşündükleri konular incelendiğinde öğrencilerden dördünün (Ö1, Ö4, Ö7, Ö8) yapacakları kitap hakkında düşündüğü görülür. Ö1'in “Nasıl bir kitap yapacağımı.”, Ö7’nin “Yaptığım kitabın güzel olup olmayacağını düşündüm.", Ö8'in "Ben de mi kitap yapsam diye düşündüm." görüşleriyle kitap yapımı ve yazılması hakkında düşünerek kitabın yapım ve yazım aşamasına ilişkin farkındalık geliştirdikleri söylenebilir. Atölye sonunda gerçekleştirilen değerlendirme etkinliğinde öğrencilerin resimlerin yazılarını yazarak kendi kitaplarını oluşturmaları öğrencilerin resimlerden yola çıkarak hikâye yazma ve kapak tasarlama kazanımlarına ulaştığını göstermektedir (Ek11). Okuma günlüğüne göre öğrencilerin tümünün kitabı okumak hoşuna gitmiştir. Öğrencilerin kitabı beğenme nedenleri kendileri yazmaları ve boyamaları olarak belirtilmiştir. Bu konudaki öğrenci görüşleri şu şekildedir: Ö4 "İçinde resim olduğu ve kendimiz yazdığımız için hoşuma gitti.", Ö7 "Çünkü kendim yazdım kitabı.", Ö9 "Çünkü ilk defa kendi kitabımı yaptım." Öğrenci görüşleri doğrultusunda, öğrencilerin özellikle kendilerinin aktif oldukları etkinliklere katılmaktan hoşlandıkları ve bu türde etkinliklerle geliştirilen okuma çalışmalarına daha ilgiyle katıldıkları görülmektedir.

\section{Altıncı atölyenin kazanımları}

"Kitap okumaya karşı istek duyar." ve "Kitabın içeriğini tahmin eder." olarak belirtilmiştir. Öğrencilerden dördü (Ö3, Ö7, Ö8, Ö9) kitap okumanın zevkli olduğunu ve kitap okumayı daha çok sevmeye başladıklarını şu cümlelerle belirtmişlerdir: "Kitap okumanın zevkli olduğunu öğrendim."(Ö3), "Kitap okumayı daha çok sevmeye başladım." (Ö7), "Bazı insanların kitapları sevmediğini ve kitap okumayı sevmeyi." (Ö9) Öğrencilerin ne düşündükleri sorusuna verdikleri yanıtlar incelendiğinde, öğrencilerden yedisinin kitapla ilgili konular düşündüğü görülmektedir. Örneğin Ö3 "Kitaptaki bilmeceleri nasıl çözeceğini", Ö4 "Ejderha olduğumu", Ö5 "Devin ne yapacağını”, Ö9 "Canlandırma yaparken kitabın nasıl olacağını düşündüm.” demiştir. Öğrencilerin tümünün kitabı okumaktan hoşlandığı belirlenmiş ve öğrencilerin kitabı beğenme nedenleri; içinde resim ve bilmece olması, komik olması ve ele alınan konu olarak belirtilmiştir. Bu konudaki öğrenci görüşlerinde bazıları: Ö2 "Kitabın içinde resim ve bilmeceler var.", Ö4 "Tavşan dişli adamın olduğu bölüm komikti.", Ö5 "Güzel resimler ve hikâyeler vardı." şeklindedir. Altıncı atölyeye ilişkin lider 
“Yaratıcı Dramayla Kitap Kurdu Olunur mu?” Çocuk Kitaplarıyla Okuma Sevgisi ve İlgisi Kazandırma

gözlemleri şu şekildedir: "Kitap okunurken ilk defa birkaç öğrencimin okuduklarını anlamlandırarak, güldüğünü ve eğlendiğini gördüm. 3-4-7-8 no'lu öğrenciler kitabı okurken, kitaptan hoşlandıkları beden dillerinden belli oluyordu. Kitabın bazı bölümlerine konulmuş bulmacalar öğrencilerin ilgisini kitaba çeken başka bir etmendi. Değerlendirme aşamasında birkaç öğrencim serbest okuma saatlerinde yaptığımız okumalarda bazen kitaplarını okumadıklarını fakat atölye sırasında kitaplarını büyük bir zevkle okuduklarını söylediler." (26.4.2016). Öğrencilerin öğrendikleri, düşündükleri, lider gözlemleri, değerlendirme etkinliklerinde kitabın sonuna ilişkin tahminleri ve kitaptan hoşlanma nedenleri göz önünde bulunduğunda öğrencilerin kitabı okumaya karşı istek duydukları ve kitabın içeriğini tahmin etmeye çalıştıkları belirlenmiştir.

Yedinci atölyenin kazanımları

"Kitap okumaya karşı istek duyar.", "Bazı hayvanların neslinin tükenmekte olduğunu fark eder." ve "Flamingolar hakkında bilgi sahibi olur." olarak belirtilmiştir. Okuma günlüğüne göre öğrencilerden üçü (Ö1, Ö4, Ö9) hayvanların soyunun tükendiğini öğrendiğini şu sözleriyle belirtmişlerdir: Ö4" Hayvanların neslinin tükendiğini öğrendim.", Ö9 "Hayvanların soyunun hızla tükendiğini öğrendim.". Öğrencilerden üçünün (Ö3, Ö6, Ö8) ise flamingolara ilişkin çeşitli bilgileri öğrendikleri görülmektedir. Ö3 "Flamingoların da nesli tükendiği için flamingoları avlamamayı", Ö6 "Flamingoların yavrusunun hangi renkte olduğunu", Ö8 "Flamingoların renkli olduğunu öğrendim." Öğrencilerden bir kısmının hayvanların neslinin tükenmekte olduğu kazanımına ulaştığı, bir kısmının da flamingolar hakkında bilgi sahibi oldukları ancak tüm öğrencilerin bu kazanımlara ulaşmadığı görülmektedir. Öğrencilerden biri (Ö5) dışında hepsi kitabı okumanın hoşlarına gittiğini belirtmişlerdir. Kitabı okumaktan hoşlanmayan Ö5'in görüşleri “Resimleri ve hikâyeyi beğenmedim ama atölyeyi beğendim." şeklindedir. Kitaptan hoşlanan diğer öğrencilerin görüşlerine göre öğrencilerin üçü (Ö1, Ö6, Ö8) içinde flamingolar olduğu için dördü (Ö2, Ö4, Ö7, Ö9) de resimleri güzel olduğu için kitabı okumanın hoşlarına gittiğini belirtmişlerdir.

\section{Sekizinci atölyenin kazanımları}

"Kitap okumaya karşı istek duyar." ve "Bir ormanı oluşturan unsurları söyler." olarak belirtilmiştir. Okuma günlüğü incelendiğinde öğrencilerin içerikten çok süreçte gerçekleştirilen etkinliklerden hoşlandıkları dikkat çekmektedir çünkü öğrencilere öğrendikleri konular sorulduğunda öğrencilerden dördü (Ö1, Ö2, Ö6, Ö8) atölyede sürecinde oynanan "Hafıza kartı oyununu öğrendim." yanıtını vermişlerdir. Öğrencilerden ikisinin (Ö6, Ö9) çiçek türlerini öğrendiğini belirttiği, üçünün (Ö4, Ö7, Ö9) ise doğaya karşı farkındalık geliştirdiği görülmektedir. Bu konudaki görüşlerini Ö4 "Hayvanları incitmemeyi", Ö7 "Müdür olduğumda fabrikama filtre taktıracağım.", Ög "Filtrelerin hayvanları koruyacağını öğrendim." şeklinde ifade etmişlerdir. Öğrencilerin ne düşündüğüne ilişkin yanıtları 
incelendiğinde öğrencilerin sürece aktif olarak katıldığı görülmektedir çünkü öğrencilerden yedisinin (Ö1, Ö2, Ö3, Ö4, Ö6, Ö7, Ö8) kitabın kurgusu üzerine kafa yorduğu ve kitabın içinde ne olduğunu merak ettiği, kitaptaki hayvanların nasıl kurtulacağını düşündükleri ve kitabın diğer bölümlerin merak ettikleri görülmektedir. Öğrencilerin bu konudaki görüşlerinden bazıları şu şekildedir: "Kitabın bir bölümünü okurken diğer bölümlerini merak ettim."(Ö1), "Kitabın içinde ne olduğunu düşündüm." (Ö2), "Hayvanların patronu ormandan nasıl göndereceğin düşündüm."(Ö3), "Hikâyede hayvanların nasıl kurtulacağını düşündüm." (Ö4). Öğrencilerin tümü kitabı okumanın hoşlarına gittiğini belirtmiş ve gerekçe olarak altısı kitabın konusunun hayvanlarla ilgili olmasını, dördü ise resimlerin komik ve güzel olmasını göstermiştir. Öğrencilerin bu konudaki görüşlerinden bazıları "Hikâyesi ve resimleri güzeldi." (Ö1), "içinde hayvanlar, yeşillikler ve insanlar olduğu için.”(Ö2), "Kitap çok komik, hayvanlar ve resimler çok güzel."(Ö7). Lider günlüğünde sekizinci atölyeye ilişkin görüşler şu şekilde belirtilmiştir: "ilk defa bazı öğrencilerimi kitabı iştahla okurken gördüm. Kitaplarını okurken teneffüs zili çalmasına ve dışarıdaki çocukların sesinin gelmesine rağmen öğrenciler dikkatlerini bozmadan kitaplarını okumaya devam ettiler. Ilk defa hiç kimse 48 sayfalık bir kitabın uzun olmasından şikâyetçi olmadı." (28.04.2016). Öğrencilerin öğrendikleri, düşündükleri ve kitaptan hoşlanma nedenleri ile lider günlüğü incelendiğinde öğrencilerin kitabı merak ederek ilgiyle okumak istedikleri kazanımına ulaştıkları ormanı oluşturan unsurları söyler kazanımına ise kısmen ulaştıkları düşünülmektedir.

\section{Dokuzuncu atölyenin kazanımları}

"Kitap okumaya karşı istek duyar.", "Bir kitaptan/ öykü karakterinden hareketle öykü yazar. “dır. Okuma günlükleri doğrultusunda öğrencilerin öğrendiklerini belirttikleri konular incelendiğinde öğrencilerden ikisinin (Ö3, Ö6) süreçte gerçekleştirilen etkinlikleri "kalemle eşini bul" öğrendiğini belirttiği, öğrencilerden üçünün (Ö1, Ö4, Ö7) okunan kitaptaki karakterden etkilenerek "kalemlerin konuşup konuşmadığı" konusuna odaklandıkları, öğrencilerden ikisinin (Ö5, Ö8) ise kitapların farklı güzellikleri olduğu ve kitap okumanın zevkli olduğunu öğrendiğini belirttiği görülür. Öğrencilerin sürece yönelik düşünceleri incelendiğinde beşinin kitap ve kurguya yönelik merak taşıdığı dikkat çekmektedir. Ö3 "Konuşan bir kalemim olursa ona ne soracağımı düşündüm”, Ö5 "Kitabın güzel mi çirkin mi olduğunu düşündüm.", Ö7 "Kitabı ne zaman okuyacağız diye düşündüm” görüşleriyle kitabı okumaya karşı istek duydukları ve kitabı merak ettiklerini göstermektedirler. Öğrencilerden biri (Ö5) dışında tümü kitabı okumaktan hoşlandığını belirtmiştir. Ö5 kitabın resimlerini beğenmediği için kitabı okumak hoşuna gitmemiştir. Öğrencilerden üçü (Ö1, Ö2, Ö3) kitaptan içindeki resimlerden dolayı hoşlandıklarını belirtirlerken öğrencilerden dördünün (Ö4, Ö6, Ö7, Ö8, Ö9) kitabın hikâyesi, kurgusu ve kahramanlarından dolayı kitaptan hoşlandıklarını belirtmeleri, öğrencilerin süreci biraz daha içselleştirdiklerini ve yüzeysel bir bakıştan daha derin bir okuma sürecine girmeye başladıklarını göstermektedir. Bazı öğrenci görüşleri: "iç̧inde macera vardı ve çocuk yazmayı ve kalemle konuşmayı 
seviyordu."(Ö4), "kitabı okuyan çocuğun kitabı sevmesi güzeldi.(Ö8)". Atölye sonu değerlendirme etkinliğinde gerçekleştirilen hikâye haritası ile hikâye yazma etkinliği ile öğrencilerin başı anlatılan bir hikâyenin devamını getirebildikleri, bir öyküden hareketle öykü oluşturabildikleri görülmektedir. Öğrencilerin öğrendikleri, düşündükleri, hoşlanma nedenleri ve değerlendirme etkinlikleri de göz önünde bulundurulduğunda atölye sonunda öğrencilerin çoğunluğunun kitap okumaya karşı ilgi duyduğu ve bir öyküden hareketle öykü yazabilme kazanımlarına ulaştıkları düşünülmektedir.

\section{Onuncu atölyenin kazanımları}

"Kitap okumaya karşı istek duyar." ve "Dinlediği melodiye uygun söz yazar." şeklindedir. Öğrencilerin öğrendikleri konular incelendiğinde öğrencilerden altısının (Ö2, Ö4, Ö5, Ö6, Ö7, Ö9) kitap ve kitabın konusu olan müzik kutusu ile ilgili olduğu görülmektedir. Öğrenilenlerden bazıları şu şekilde belirtilmiştir: "Fer'in müzik kutusunun şarkısını."Ö2, "Müzik kutusu nasıl çalıyor onu öğrendim." Ö4, “Müzik yapmayı öğrendim.” Ö7, "Müzik kutusunun içindeki oyuncakları öğrendim.” Ö8. Öğrencilerin süreçteki düşünceleri incelendiğinde, öğrencilerin yedisinin (Ö2, Ö3, Ö4, Ö6, Ö7, Ö8, Ö9) kitabın içeriği ve kitaba yönelik merak şeklinde olması yapılan çalışmaların kitaba duyulan ilgiyi daha arttırdığını göstermektedir. Bazı görüşleri şu şekildedir: Ö2 "Kitabın içindekileri düşündüm.", Ö3 "Fer'in çocuğunun neden uyumadığını", Ö8 "Kitabın adının ve müziğin çok güzel olduğunu düşündüm.". Öğrencilerin tümünün kitabı okumanın hoşlarına gittiğini belirtmeleri de yapılan çalışmaların öğrencilerde kitaba yönelik olumlu bir ilgi ve tutum geliştirdiğini göstermektedir. Okuma günlüğünden ulaşılan öğrenilenler, düşünceler ve hoşlanma nedenleri ile öğrencilerin büyük bölümünün kitabı okumaya istek duyduğu ve değerlendirme çalışmasında gerçekleşen söz yazma etkinliği ile öğrencilerin dinlediği melodiye uygun söz yazma kazanımına ulaştığı söylenebilir. Lider günlüğünde bu durum şu şekilde belirtilmiştir: "Değerlendirme aşamasında müzik kutusundan çıkan melodiye şarkı yazarken zorlanacaklarını düşündüm fakat iki öğrencim dışında etkinliğe katıım tamdı ve güzel ürünler ortaya çıktı." (04.05.2016)

\section{On birinci atölyenin kazanımları}

"Kitap okumaya karşı istek duyar." ve "Okuduğu kitabın sonu hakkında çıkarımda bulunur." olarak belirtilmiştir. Öğrencilerin okuma günlüğüne belirttikleri öğrendikleri konular incelendiğinde öğrencilerden biri (Ö3) dışında tümünün kitaplara ilişkin bir öğrenme gerçekleştirdiği görülmekte, Ö3 ise süreçte oynanan oyunu öğrendiğini belirtmiştir. Öğrencilerin öğrendiklerini belirttikleri konular şu şekilde gösterilebilir: "Kitapların neşeli olduğunu." (Ö5), "Kitabın nasıl yararlı olduğunu öğrendim." (Ö6), “Kitaptan bıkmamayı öğrendim.”(Ö7), “Kitap okumayı daha eğlenceli hale getirebileceğimi.”(Ö8), “Bazı çocukların kitaptan korktuğunu. “(Ö1, Ö9). Ne düşündükleri öğrenilen öğrencilerden dördünün kitabın konusu ya da kitabı okumaya ilişkin merak geliştirdikleri şu şekilde 
örneklenebilir: "Annesinin neden çocuğa ayakkabı almadığını düşündüm."(Ö3), "Kitabın ne kadarını okuyup okumayacağımızı düşündüm."(Ö7), “Kitabı düşündüm."(Ö9). Tüm öğrencileri kitabı okumaktan hoşlandıklarını belirtmeleri ve özellikle Ö5'in "Uzun olmasına rağmen güzeldi." şeklindeki yorumu ve öğrencilerin resimlerin yanı sıra anlatılan olay ve hikâyeden dolayı kitabı beğenmeye başlamaları öğrencilerin giderek okumaya ilişkin tutumlarının geliştiğini ve okuma ilgilerinin arttığını göstermektedir. Lider günlüğünde atölye ile ilgili şu not alınmıştır: "5 numaralı öğrencimin genel anlamda kalın kitap görme korkusu vardı. Onun için 40 sayfalık bir kitap kalın ve sıkıcı kitap demek oluyordu ama bugün ilk defa okuduğumuz kitap için "uzun ama güzel bir kitap" dedi. "(05.05.2016). Okuma günlüğü, lider günlüğü ve atölye sonu değerlendirme etkinliğinde gerçekleştirilen kitabın sonunu çizme etkinliği incelendiğinde öğrencilerin kitaba yönelik çıkarımlarda bulundukları ve kitap okumaya karşı istek duyar atölye kazanımlarına ulaşıldığı görülmektedir.

\section{Tartışma, Sonuç ve Öneriler}

"Yaratıcı drama ile kitap kurdu olunur mu?" başlıklı bu çalışmada öğrencilerin yaratıcı drama yöntemiyle işledikleri kitaplarla okuma ilgi ve sevgisini geliştirmek amaçlanmıştır. Araştırma kapsamında ulaşılan bulgulardan hareketle yaratıcı dramayla gerçekleştirilen okuma etkinliklerinin ardından öğrencilerin okumayı sevme durumlarında bir değişiklik olmamıştır. Ancak yaratıcı drama yöntemiyle gerçekleştirilen etkinlikler ile öğrenciler kitabın akışını ve sonunu zihinlerinde canlandırabildiklerini yani somutlaştırabildiklerini belirtmişlerdir. Çalışma sonuçları Lin (1999)'in çalışmasıyla benzerlik göstermektedir; öyküler canlandırıldığında ve benzetmeler yapıldığında öğrenciler daha iyi performans göstermiştir. Yaratıcı drama çalışmalarının öğrencilerin metni anlama düzeyini ve zihinlerinde canlandırmasını kolaylaştırması sonucu, Susar Kırmızı (2008)'nın yaratıcı drama yöntemiyle desteklenen okuduğunu anlama çalışmalarıyla okuma sürecinin aktif bir şekilde gerçekleştiği sonucuyla da örtüşmektedir. Susar Kırmızı (2008: 108)'nın araştırması sonucunda öğrenci görüşlerine, yaratıcı dramayla gerçekleştirilen okuma etkinliklerinin öğrencilerin metni daha kolay anlamalarına, metne kendini kaptırmalarına ve kendilerini kitabın içindeymiş gibi hayal etmelerine yardımcı olduğu görülmüştür. Kara (2010)'nın çalışmasına göre de yaratıcı drama yöntemi öğrencilerin kendilerini şahıs ya da varlıkların yerine koymalarına, duygu, düşünce ve hayallerini yorumlamalarına, yaratıcılık ve hayal güçlerinin gelişmesine katkı sağlamaktadır.

Çalışma başında öğrencilerin genelinin televizyon izlemeyi kitap okumaya tercih ettiği ancak yaratıcı drama çalışmalarıyla gerçekleştirilen okuma etkinliklerinin ardından öğrencilerden üçünün boş zaman etkinliği tercihini kitaptan yana olumlu yönde etkilediği belirlenmiştir. Yaratıcı drama çalışmalarıyla gerçekleştirilen okuma etkinliklerinin öğrencilerin bazılarının süreç boyunca eğlenerek kitap okumaya ilgisini arttırdığı söylenebilir. Öğrencilerin kitap okumama nedenlerini araştıran bir araştırmaya göre (Arıcı, 2008) okumayı sevmeyen gençlerin okumama nedenlerinden bazıları; 
“Yaratıcı Dramayla Kitap Kurdu Olunur mu?” Çocuk Kitaplarıyla Okuma Sevgisi ve İlgisi Kazandırma

kitapların bazılarını sıkıcı ve pahalı bulmaları, çocuklukta bu alışkanlığı kazanamamaları, boş zamanlarının olmaması, gazete ve dergi okumayı tercih etmeleri, TV izleme, film seyretme ve interneti kitap okumaya göre daha zevkli bulmalarıdır. Aksaçlıoğlu ve Yılmaz (2007)'ın araştırma sonuçlarına göre ilköğretim öğrencilerin boş zamanlarında kitap okumayı, bilgisayar kullanma ve televizyon izleme etkinliğinden daha sonra tercih ettiği, bilgisayar kullanma süresi ve televizyon izleme süresi ile kitap okuma sıklığı arasında ters orantılı bir ilişkinin olduğu anlaşılmıştır. Duran ve Sezgin (2012)'in araştırmaları da benzer sonuçları ortaya koymaktadır ilköğretim öğrencileri orta ve alt düzey okuyucudurlar. Bu öğrencilerin tamamına yakını, gün içerisinde okumaktan ziyade, TV seyretmeyi veya internette oyun oynamayı tercih etmektedirler. Bu nedenle yaratıcı drama gibi etkileşimli yöntemlerle gerçekleştirilecek okuma çalışmalarının öğrencilerin kitap okumanın sıkıcı olmadığını anlayarak boş zaman tercihlerini okumadan yana kullanmalarını sağlayacağı düşünülmektedir.

Yaratıcı drama çalışmalarının öğrencilerin okuma sıklığıı tam anlamıyla geliştirmediği ancak öğrencilerin kitap okuma eylemini daha düzenli bir şekilde gerçekleştirmelerini desteklediği belirlenmiştir. Öğrencilerin çoğunluğu yaratıcı dramayla gerçekleştirilen kitap okuma atölyelerinde belirlenen kazanımlara ulaşmış olup atölye sonlarında öğrencilerin istekli bir şekilde kitap okumaları çalışma kapsamında ulaşılan en önemli sonuçtur.

Araştırma kapsamında araştırmacı gözlemlerinden hareketle de çeşitli sonuçlara ulaşılmıştır. Araştırmacı gözlemlerine göre yöntem olarak yaratıcı drama kullanılması, kitap ve öğrenci arasında bir bağ kurulmasını sağlamıştır. Öğrenci, kitabı içselleştirerek okurken kitaba karşı yabancılık çekmemiştir. Böylelikle kitap okumak öğrenci için bir iş olmaktan çıkıp eğlendiği bir etkinlik haline gelmiştir. Atölye boyunca özellikle canlandırma aşamalarında öğrencilerin kitap kahramanlarının yerine kendilerini koymaları onun gibi hissetmeye çalışmaları onlar için kitap okumayı eğlenceli hale getirmiş, öğrencilerin ilk defa kitap okurken güldükleri gözlemlenmiştir. Bu sonuç Kara (2010)'nın çalışmasıyla da destekelenmektedir. Kara (2010)'ya göre, ilköğretim ikinci kademe öğrencileri dramayla öykü oluşturma etkinliklerini genel anlamda "eğlendirici" bulmaktadırlar ve Türkçe dersinde dramayla öykü oluşturma yönteminin kullanılması ilköğretim ikinci kademe öğrencilerinin Türkçe dersine olan ilgi ve tutumlarını olumlu yönde arttırmaktadır.

Yaratıcı drama yönteminin öğrencilerin okumaya karşı ilgilerini arttırmasının yanı sıra Türkçe dersine ilişkin tutumlarını olumlu yönde etkilediği de görülmektedir. Yıldırım ve Erdoğan (2016)'ın ilkokul ikinci sınıf öğrencileriyle Türkçe dersi kapsamında sağlık ve çevre teması kapsamında yaratıcı drama yöntemiyle gerçekleştirilen etkinliklerin öğrencilerin Türkçe dersine yönelik tutumlarını olumlu etkilediği sonuçlarına ulaşılmıştır. Yine Aslan ve arkadaşlarının (2011) çalışmasına göre yaratıcı drama 
yönteminin uygulandığı deney grubu öğrencilerinin Türkçe dersine yönelik tutumlarının geleneksel yöntem uygulanan öğrencilere göre daha olumlu yönde etkilendiği görülmüştür.

Öğrencilerin atölye çalışmalarında fikirlerini paylaşmaları, canlandırmalar yapmaları ve sonunda atölyesi yapılan kitabı birlikte okumaları, süreç sonunda kitabı tartışma ve kitap hakkında konuşma yönünde onları güdülemiştir. Yaratıcı drama yöntemiyle kitap okuma etkinlikleriyle; öğrencilerde kitap okuma dikkati, merakı ve isteği gelişmiştir. Örneğin çalışmalardan önce kitabı ellerine alan öğrenciler ilk olarak sayfa sayısına bakmaktayken çalışma sonunda öğrencilerin ilk olarak kitabın yazarına, kitap sırtına, kaçıncı baskı olduğuna ve görsellerine baktıkları gözlemlenmiştir.

Çalışma sonucunda şu önerilerde bulunulabilir: çalışmada gerçekleştirilen atölyelerin esnek bir çerçevesi olduğu için okuma ilgi ve sevgisi kazandırma kazanımına yönelik olarak farklı grup, kitaplar ve yaş düzeyleriyle de benzer çalışmalar yapılmasının önerilmektedir. Çocuğun okuma alışkanlığı kazanmasında özellikle aile ve kütüphanelerin de içinde bulunduğu eğitim kurumlarının çok büyük önemi bulunmaktadır. Küçük yaşlardaki çocuklar öncelikle aile bireyleri, ardından öğretmenleri, daha sonra aile yakınları, komşular, arkadaşlar ve kütüphane görevlileri gibi yaşam alanlarının içinde olan kişileri kendilerine örnek alırlar. Bu nedenle çocukları kitaplarla karşılaştıran öğretmenlerin çocuklara uygun çocuk kitaplarını seçebilecek ve etkileşimli yöntemlerle çocuk ve kitap arasında bağ kurabilecek nitelikte donanımlı olması önerilmektedir.

\section{Kaynaklar}

Adıgüzel, F., Akfırat, i. (2014). Türkiye'de gerçekleştirilen dil - edebiyat ve yaratıcı drama çalışmalarında Alman oyun ve tiyatro pedagoglarının izleri. Theater und Community - Kreativ Gestalten (Kültür ve ToplumYaratıcı Biçim Vermek) (Ed. Adıgüzel, Ö.,U. Handwerg, G. Koch) Schriftenreihe Kulturelle Bildung:München ISBN 978-386736-342-6

Adıgüzel, Ö. (2012). Eğitimde yaratııı drama. (2. Basım). Ankara: Naturel Yayıncılık.

Adıgüzel, Ö. (2006). Yaratııı drama kavramı, bileşenleri ve aşamaları. Yaratııı Drama Dergisi. C1(1), 17-29.

Akfırat, H. I. (2009). Öykü ve Masal Türlerinde Yaratııı Drama Yöntemiyle Yapısal Çözümleme ve Tema Belirleme. Yayımlanmamış dernek projesi, Ankara: T. C. MEB Özel Doğaç.

Aksaçlığlu, A.G., Yılmaz, B. (2007). Öğrencilerin televizyon izlemelerinin ve bilgisayar kullanmalarının okuma alıskanlıkları üzerine etkisi. Türk Kütüphaneciliği, 21(1), 3-28.

Alpay, M. (1990). Çocuk ve kütüphanesi: Okulöncesi dönem kütüphane. Dünü Yarına Bağlayan Köprü İ̧̧inde (s.79-84), İstanbul: Türk Kütüphaneciler Derneği.

Arııı, A. F. (2008). Okumayı niye sevmiyoruz? Üniversite öğrencileri ile mülakatlar, Mustafa Kemal Üniversitesi Sosyal Bilimler Enstitüsü Dergisi, 5 (10), 91-100.

Arslan, A., Şahin, A., Şahin, E., Akçay, A. (2011). Yaratıcı Drama Yönteminin Ilköğretim 6. Sınıf Öğrencilerinin Türkçe Dersi Tutumlarına Etkisi. Millî Eğitim. (1)190, 234-247.

Ataman, M. (2006). Yaratııı drama sürecinde yaratıcı yazma. Yaratııı Drama Dergisi. C1, 74-83.

Aykaç, M., İlhan, A.Ç. (2014). Çocuk edebiyatı metinleriyle kurgulanan yaratıı drama etkinliklerinin konuşma becerilerine etkisi. Ankara Üniversitesi Eğitim Bilimleri Dergisi. 47, 216-217. 
Aykaç, M. (2011). Türkçe öğretiminde çocuk edebiyatı metinleriyle kurgulanan yaratıcı drama etkinliklerinin anlatma becerilerine etkisi. Yayımlanmamış doktora tezi, Ankara Üniversitesi Eğitim Bilimleri Enstitüsü, Ankara.

Bamberger, R. (1990). Okuma alışkanlığını geliştirme. (1.Basım). Ankara: Kültür Bakanlığı Yayınları.

Bircan, İ. ve Tekin, M. (1989). Türkiye'de okuma alışkanlığının azalması sorunu ve çözüm yolları. Ankara Üniversitesi Eğitim Bilimleri Fakültesi Dergisi, 22(1), 393-410.

Çekerol, S., Kurulgan, M. (2008). Öğrencilerin okuma ve kütüphane kullanma alışkanlıkları üzerine bir araştırma. Anadolu Üniversitesi Sosyal Bilimler Dergisi. 8, 2, 238-239.

Çınar, H. (2005). Masal atölyesi projesi. Türkiye 7. Drama Liderleri Buluşması ve Ulusal Drama Semineri, 24-26 Haziran 2005 (syf. 125-132), Ankara: Oluşum Yayınları.

Çocuk Vakfı (2006). Türkiye'nin okuma alışkanlığı karnesi, İstanbul: Çocuk Vakfı Yayınları.

Duran, E., Sezgin, B. (2012). İlköğretim 4. ve 5. sınıf öğrencilerinin okuma alışkanlıklarının ve ilgilerinin belirlenmesi. Turkish Studies - International Periodical For The Languages, Literature and History of Turkish or Turkic Volume 7/4, Fall 2012, p. 1649-1662, ANKARA.

Gökalp, G. G. (1998). Okuma eğitimi ve etkin okur kimliği, Türkçenin Öğretimi ve Eğitimi, Sempozyum Bildirileri (5-6 Haziran 1998), Ankara: A.Ü. TÖMER Gaziantep Şubesi Yayınları.

Gültekin, A. (2008). Çocuk ve gençlerde okuma kültürü oluşturmada çocuk ve gençlik edebiyatı eğitiminin önemi. Çocuk ve Okuma Kültürü Sempozyumu (24-25 Mayıs 2008) Kitabı, Ankara: Eğitim Sen Yayınları.

Kara, Ö.T. (2010). Dramayla öykü oluşturma yönteminin ilköğretim ikinci kademe öğretimine etkisi. Yayımlanmamış doktora tezi, Konya: Selçuk Üniversitesi Eğitim Bilimleri Enstitüsü.

Karabağ, H. H. (2005). Dramada bir anlatı biçimi olarak masal. Türkiye 7. Drama Liderleri Buluşması ve Ulusal Drama Semineri, 24-26 Haziran 2005 (syf. 93-100), Ankara: Oluşum Yayınları.

Kültür ve Turizm Bakanlığı Türkiye Okuma Kültürü Haritası (2014) http://www.kygm.gov.tr/Eklenti/55,yoneticiozetipdf.pdf?0

Layiç, Ş. (2008). Masallar ve yaratıcı drama. Yayımlanmamış dernek projesi, Ankara: T. C. MEB Özel Doğaç.

Lin, M.S. (1999). The effects of creative drama on story comprehension for children in Taivan. Unpublished doctoral dissertation, Arizona State University.

MEB (EARGED). (2007). Öğrencilerin okuma düzeyleri. Ankara: MEB Kaynak Kitaplar Dizisi. http://yegitek.meb.gov.tr/tamamlanan/okuma_duzey.pdf

Odabaş, H., Odabaş Y. ve Polat, C. (2008). Üniversite öğrencilerinin okuma alışkanlığı: Ankara üniversitesi örneği. Bilgi Dünyası, 9(2), 431-465.

Öz, F. (2001). Uygulamalı Türkçe öğretimi. (1.Basım). Ankara: Anı Yayıncılık.

Özyılmaz, S. (2008). Klasik masallar ve drama. Yayımlanmamış dernek projesi, Ankara: T. C. MEB Özel Doğaç.

San, ì. (2002). "Yaratıcı drama -eğitsel Boyutları" .Yaratıcı Drama 1985-1995 Yazılar. (Edt. H. Ömer Adıgüzel) Ankara: Natürel Yayınları.

Saracaloğlu, A. S., Bozkurt, N. ve Serin, O. (2003). Üniversite öğrencilerinin okuma ilgileri ve okuma alışkanlıklarını etkileyen faktörler, Eğitim Araştırmaları Dergisi, 12, 148-157.

Sever, S. (2011). Türkçe öğretimi ve tam öğrenme. (5.Basım). Ankara: Anı Yayıncılık.

Sever, S. (2013). Çocuk edebiyatı ve okuma kültürü. İzmir: Tudem Yayınevi.

Sevim, E. (2006). Yaratıcı drama ve masallar. Yayımlanmamış dernek projesi, Ankara: T. C. MEB Özel Doğaç.

Susar Kırmızı, T. (2008). Türkçe öğretiminde yaratıcı drama yönteminin tutum ve okuduğunu anlama stratejileri üzerindeki etkisi. Pamukkale Üniversitesi Eğitim Fakültesi Dergisi, (1), 23, 95-109. 
TUik (2015). Uluslararası Standart Kitap Numarası (ISBN) İstatistikleri. http://www.tuik.gov.tr/PreHaberBultenleri.do?id=21541

Yıldırım, A., Şimşek, H.(2013). Sosyal bilimlerde nitel araştırma yöntemleri. 9. Baskı. Ankara: Seçkin Yayınevi.

Yıldırım, M. Erdoğan, Tolga (2016). Yaratıcı drama yönteminin ilkokul ikinci sınıf öğrencilerinin Türkçe dersine ilişkin tutumlarına etkisi. Yaratıcı drama dergisi. 11(1), 71-88.

Yıldız, D., Ceran, D., Sevmez, H. (2015). Eğitim fakültesi öğrencilerinin okuma alışkanlıkları profili. Uşak Üniversitesi Sosyal Bilimler Dergisi, 8/3, 141-166.

Yıldız, M. (2013). İlköğretim 3, 4 ve 5. sınıf öğrencilerinin okuma motivasyonlarının incelenmesi. Eğitim ve Bilim Dergisi. 38, 168-268.

Yılmaz, B. (2004). Türkiye'de eğitim politikası ve kütüphane. Ankara: Türk Kütüphaneciler Derneği Ankara Şubesi.

Yılmaz, B. (1998). Okuma alışkanlığı sorunu, bir enstitü örneği ve Türkiye için öneriler. Türk Kütüphaneciliği, 12 (3), 244-251.

Yılmaz, N. (2008). Yaratıcı drama teknikleri ile çocuk kitaplarının yaratıcı düşünme ve sorun çözme aracı olarak kullanımı. Yayımlanmamış dernek projesi, Ankara: T. C. MEB Özel Doğaç.

Yılmaz, N. (2009). Yaratıcı drama destekli yaratıcı okuma programı. Yaratıcı Drama Dergisi, 4(7), 93-115.

Yılmaz, Z. A. (2006). Sınıf öğretmeni adaylarının okuma alışkanlığı. İlköğretim Online, 5(1): 1-6.

\section{Çocuk Kitapları Kaynakçası}

Ak, B. (2012). Doğumgünü Hediyesi. (3.Basım). İstanbul: Can Sanat Yayınları.

Çakman, K.A. (2015). Flamingo Günlüğü. (1.Basım). İstanbul: Can Sanat Yayınları.

Dubini, M. (2015). Okumayı Sevmeyen Çocuğun Hikâyesi. (1.Basım). İstanbul: Yapı Kredi Yayınları.

Dubini, M. (2014). Yazmayı Sevmeyen Çocuğun Hikâyesi. (1.Basım). İstanbul: Yapı Kredi Yayınları.

Erdoğan, N. (2015). Palyaçobalığı Palya. (1.Basım). İstanbul: Yapı Kredi Yayınları.

Faruk, Ö. (2012). Defne Ağacı ve Orman Kardeşliği. (1.Basım). İstanbul: Yapı Kredi Yayınları.

Kaplangı, Ç. (2015). Bozuk Müzik Kutusu. (1.Basım). İstanbul: Yapı Kredi Yayınları.

Reynolds, P.R. (2014). Mış Gibi. (3.Basım). İstanbul: Altın Kitaplar Yayınevi.

Tamaro, S. (2016). Kitaplardan Korkan Çocuk. (39.Basım). İstanbul: Can Sanat Yayınları. 


\section{EKLER}

Ek 1: Yaratıcı Drama Örnek Ders Planı

Konu: "-mış gibi"

Tarih: 08.04.2016

Süre: 120 dakika

Mekân: ... İlkokulu 3-A Sınıfı

Grup: 3. sınıf öğrencileri (4 erkek- 5 kız)

Yöntem: Yaratıcı drama

Teknik: Rol oynama ve doğaçlama

Araç - gereç:9 adet A4 kâğıdı, 9 adet kraft kâğıdı, 3 kutu pastel boya, 9 adet kurşun kalem, yapışkanlı kağıt, hamur yapıştırıcı, 9 adet "-Mış Gibi" isimli kitap.

Kazanım:

- Kitap okumaya karşı ilgi duyar.

- Kitabın içeriği hakkında çıkarımlarda bulunur.

\section{SÜREÇ}

\section{A. Isınma - Hazırlık}

1. Etkinlik: Katılımcılar ve lider çember oluşturur. Lider, katılımcıların mekânda müzik eşliğinde dağınık bir biçimde yürümeleri yönergesini verir. Lider "Şimdi robotmuş gibi yürüyoruz... Kuşmuş gibi uçuyoruz... Suymuş gibi akıyoruz... Güneşmiş gibi hareket ediyoruz... Arıymış gibi kanat çırpıyoruz... Filmiş gibi hareket ediyoruz... Yağmurmuş gibi yağıyoruz..." der. Lider, katılımcılarında isterlerse içerisinde -mış gibi eylemler geçen hareketler bularak tüm gruba yaptırabileceklerini söyler.

2. Etkinlik: Lider, kitapta yer alan -mış gibi çizilmiş resimleri buruşturulmuş halde mekânın ortasına bırakır ve herkesin yerden bir buruşturulmuş kâğıt alıp kimseye göstermeden açmasını söyler. Katılımcılara gördükleri resimlerin onlara göre neye benzediğini düşünerek; sessiz, sözsüz, hareketsiz bir beden formu ya da heykel formu oluşturmalarını söyler. Lider “Hazır olan katılımcıdan başlayarak sırayla beden formlarınızı veya heykellerinizi sergileyeceksiniz. Diğer katılımcılarda oluşturulan heykelin neye benzediğini tahmin etmeye çalışacaklar" der. Katılımcılardan tek tek cevaplar alındıktan sonra kâğıtlar mekânda belirlenen bir yere yan yana yapıştırılır.

Ara Değerlendirme: Lider, katılımcılara "Bu resimleri Ramon isimli bir çocuk yaptı. O da sizler gibi resim yapmayı çok seviyor. Resim yaparken resminin yaptığı şeye benzeyip benzememe gibi bir kaygısı yok. Sadece içinden geldiği için, hayal gücünü kısıtlamadan resim yapıyor.

Lider: Sizce neden o resimler hakkında herkesin farklı bir fikri vardı?

K1: Onun düşüncesi o.

K2: Herkesin kafasında farklı farklı canlanıyor.

Lider: Sizde bu resimlere benzer resimler çiziyor musunuz?

K3: Yapmaya çalışıyorum

Lider: Ben resim yapamıyorum dediğiniz zamanlar oluyor mu?

K4: Olmuyor.

K5: Canım istemediğinde yapmak istemiyorum sadece.

Lider: Sizce Ramon'un çizdiği resimler yanlış çizilmiş resimler mi? Neden?

K6: Hayır. Öyle çizmek istemiş.

3.Etkinlik: Lider katılımcılara yapışkanlı kâğıt verir ve duvara yapıştırılan her bir resim için neye benziyormuş gibi oldukları yazılıp, resimlere yapıştırmalarını söyler. Resimlere kâğıtlar yapıştırıldıktan sonra katılımcılar üç gruba ayrılır ve her grubun duvardaki resimlerden 15 tane yapışkanlı kâğıt almaları söylenir. Lider, gruplara "Yapışkanlı kâğıtlardaki kelimeleri kullanarak bu resimlerle ilgili bir şiir oluşturacaksınız. Şiirler yazıldıktan sonra tüm katılımcılara okuyacağız" der.

\section{B. Canlandırma}

4.Etkinlik: Katılımcılar ikili grup olurlar ve kendi aralarında A-B olarak ayrılırlar. Lider A'lar ile B'lere aşağıdaki yönergeleri verir: 
B'lerin Dramatik Durumu: Siz resim yapmayı çok seviyorsunuz ama yaptığınız resimleri abiniz bir şeye benzetemediği için sizin resimlerinizle ilgili komik şeyler söyleyip, dalga geçiyor. Bir gün siz resim yaparken abiniz yine yanınıza gelip yaptığınız bir resimle ilgili sizinle dalga geçince ona kızarak "Neden yapıyorsun bunu?" diye soruyorsunuz.

A'ların Dramatik Durumu: Siz resim yeteneği iyi olan birisiniz. Kardeşinizin yaptığı çizimleri biçimsiz ve komik buluyorsunuz. Bir gün yine kardeşinizin yanına gidip onun resimleriyle dalga geçiyorsunuz. Fakat kardeşinizden hiç beklemediğiniz bir tepki alıyorsunuz. Katılımcılar eş zamanlı olarak doğaçlamaya başlar. Doğaçlamalar bittikten sonra eşlerin sırayla canlandırmaları izlenir. Aynı süreç roller değiştirilerek devam eder.

Ara Değerlendirme: Lider, "Sizce abinin kardeşine bu şekilde davranması doğru mu? Neden?" sorularını sorar.

K1: Hayır. O resimler abisine göre çirkin çocuğa göre güzel resimlerdir.

K2: Kardeşinin hayal gücünü bozuyor abisi.

K3: Kardeşinin kalbini kırıyor. Belki kardeşi ressam olmak istiyor.

Lider: Siz kardeş olsaydınız ne yapardınız? Neden?

K4: Onun resmine eşlik ederdim birlikte duvarlara asardık.

K5: Kalbini kırmamaya çalışırdım ve ona yardım ederdim.

5. Etkinlik: Katılımcılar iki gruba ayrılır. Lider gruplara kraft kâğıdı ve hikâyenin resimlerini karmaşık bir şekilde dağıtır. Gruplar önce resimleri sıralamalı ardından da altlarına kendi hikâyelerini yazmalıdırlar. Kendi hikâyelerini yazdıktan sonra lider, her gruba kendi hikâyesini canlandırmasını söyler.

\section{Değerlendirme}

6. Etkinlik: Lider katılımcılara kitabı dağıtmadan önce öğrencilere kitabı okuyup okumak istemediklerini sorar aldığı olumlu yanıt üzerine onlara kitabı dağıtarak okumalarını söyler. Kitap okunduktan sonra lider katılımcılara birer A4 kâğıdı verir ve şu soruları sorar.

-Ramon -mış gibi çiçekler, ağaçlar, güneşler çizdi. Siz Ramon olsaydınız"-mış gibi" ne çizmek isterdiniz? Neden?

-Resim çizerken bir şeyi aynen resimlemek zorunda mıyız?

-Okuduğunuz kitap hakkında ne düşünüyorsunuz?

-Okumaktan hoşlandınız mı? Neden?

-En çok hangi bölümünden hoşlandınız? Neden?

Lider katılımcılardan Ramon gibi resimler çizmelerini ve yapılan resimlerin altına .......mış gibi (örnek: çiçekmiş gibi) yazmalarını söyler. Çizimler bittikten sonra lider her katılımcıya neden o resmi çizdiğini sorar. Katılımcılar paylaşımda bulunduktan sonra resimler mekânın çeşitli yerlerine yapıştırılarak atölye sonlandırılır.
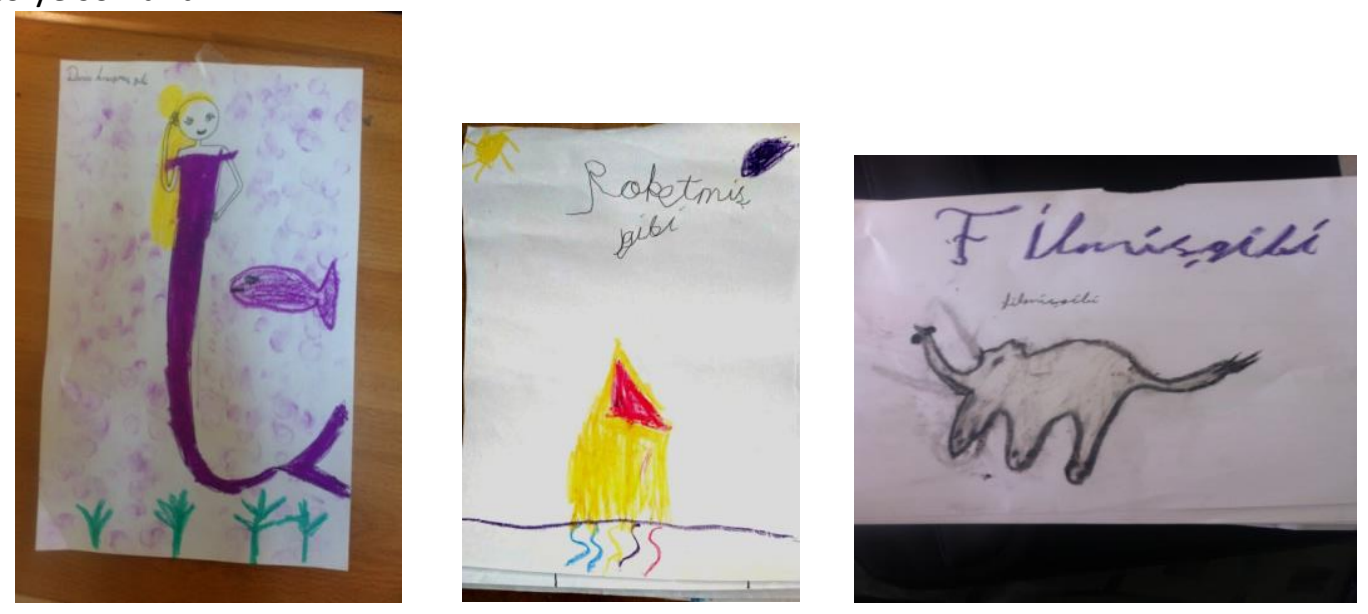